\title{
Year-round shellfish exploitation in the Levant and implications for Upper Palaeolithic hunter-gatherer subsistence
}

\author{
Authors \\ Marjolein D. Bosch ${ }^{\mathrm{a}, \mathrm{b}^{*}}$, Marcello A. Mannino ${ }^{\mathrm{c}, \mathrm{a}}$, Amy L. Prendergast ${ }^{\mathrm{d}}$, Frank P. Wesselingh ${ }^{\mathrm{e}}$, Tamsin C. \\ $\mathrm{O}^{\prime}$ Connell ${ }^{f}$ and Jean-Jacques Hublin ${ }^{a}$ \\ ${ }^{\text {a }}$ Department of Human Evolution, Max Planck Institute for Evolutionary Anthropology, Deutscher Platz \\ 6, D-04103 Leipzig, Germany \\ ${ }^{b}$ McDonald Institute for Archaeological Research, University of Cambridge, Downing Street, Cambridge, \\ CB2 3ER, United Kingdom \\ ${ }^{\mathrm{C}}$ Department of Archaeology and Heritage Studies, School of Culture and Society, Aarhus University, \\ Moesgård Allé 20, DK-8270 Højbjerg, Denmark \\ ${ }^{\mathrm{d}}$ School of Geography, The University of Melbourne, 221 Bouverie St, Carlton, 3053, Australia \\ ${ }^{\mathrm{e}}$ Naturalis Biodiversity Center, Postbus 9517, 2300 RA Leiden, the Netherlands \\ ${ }^{\mathrm{f}}$ Department of Archaeology and Anthropology, University of Cambridge, Downing Street, Cambridge \\ CB2 3DZ, United Kingdom \\ *corresponding author: dmb75@cam.ac.uk
}

\section{Keywords}

Subsistence behavior, Levantine Upper Paleolithic, shellfish exploitation, oxygen isotope analysis, seasonality, Ksâr 'Akil, Phorcus turbinatus

\section{Highlights}

- Oxygen isotope analysis conveys year-round shellfish exploitation at Ksâr 'Akil

- Coastal resources had a central role in Early Upper Paleolithic foraging strategies

- During most of the Upper Paleolithic, Ksâr 'Akil was inhabited throughout the year

- The EUP occupants of Ksâr 'Akil had a broader diet than their IUP forbearers

\begin{abstract}
Recent studies have shown that the use of aquatic resources has greater antiquity in hominin diets than previously thought. At present, it is unclear when hominins started to habitually consume marine resources. This study examines shellfish exploitation from a behavioural ecology perspective, addressing how and when past hunter-gatherers from the Levant used coastal resources for subsistence purposes. We investigate the seasonality of shellfish exploitation in the Levantine Upper Palaeolithic through oxygen isotope analysis on shells of the intertidal rocky shore mollusc Phorcus (Osilinus) turbinatus from
\end{abstract}


the key site Ksâr 'Akil (Lebanon). At this rockshelter, multi-layered archaeological deposits contained remains of both marine and terrestrial molluscs in relatively large quantities, which were consumed and used as tools and ornaments by the occupants of the site. Our results indicate that at the start of the Initial Upper Palaeolithic (IUP), there is no evidence for shellfish consumption. Humans started to take fresh shellfish to the rockshelter from the second half of the IUP onward, albeit in low quantities. During the Early Upper Palaeolithic (EUP) shellfish exploitation became increasingly frequent. Oxygen isotope data show that shellfish exploitation was practised in every season throughout most of the Upper Palaeolithic (UP), with an emphasis on the colder months. This suggests that coastal resources had a central role in early UP foraging strategies, rather than a seasonally restricted supplementary one. Yearround shellfish gathering, in turn, suggests that humans occupied the rockshelter at different times of the year, although not necessarily continuously. Our oxygen isotope data is complemented with broader-scale exploitation patterns of faunal resources, both vertebrate and invertebrate, at the site. The inclusion of coastal marine resources signifies a diversification of the human diet from the EUP onward, which is also observed in foraging practices linked to the exploitation of terrestrial fauna.

\section{Introduction}

Recent archaeological discoveries indicate that the exploitation of aquatic resources has a long history among various hominin species. The earliest evidence of the exploitation of freshwater fish was documented from Koobi Fora, Kenya about 1.95 million years ago (Braun et al. 2010) for Homo ergaster/erectus, who made Oldowan tools. Homo erectus individuals may have consumed freshwater molluscs from approximately $\geq 400$ thousand years ago (kya) in Trinil (Java, Indonesia) (Joordens et al. 2014). During Marine Isotope Stages (MIS) 6 and 5 (roughly 190-125 kya and 125-80 kya, respectively), Middle Stone Age (MSA) Homo sapiens exploited shellfish at several South African coastal sites (e.g. Klein et al. 2004; Avery et al. 2008; Jerardino and Marean 2010; Langejans et al. 2012; Clark and Kandel 2013; Kyriacou et al. 2015; Jerardino 2016). In the Mediterranean region, marine molluscs were exploited during the Middle Palaeolithic both by $\mathrm{H}$. sapiens and Homo neanderthalensis from MIS 5 onward (e.g., Emiliani et al. 1964; Klein and Scott 1986; Stiner 1999; Finlayson et al. 2006, 2008; Colonese et al. 2011; Cortés-Sánchez et al. 2011; Barker et al. 2012; Fa et al. 2016).

Thus, aquatic resources played a role in early hominin diets, although their contribution has been considered as marginal for most of the Palaeolithic (e.g., Erlandson and Moss 2001; Colonese et al. 2011; Clark and Kandel 2013; Jerardino 2015). This is especially true when optimal foraging models are used, which primarily consider the caloric value and energy intake of foodstuffs (see also Grayson and Delpech 1998; Stiner, 2001, 2010). However, from a nutritional ecology perspective, shellfish are a rich source of many essential nutrients, including vitamins (i.e., A, B12, C, D, and E), iron, folate, potassium, calcium, and omega-3 fatty acids (e.g., Hockett and Haws 2003; Haws and Hockett 2004; Cunnane and Crawford 2014; Kyriacou et al. 2015). Due to their high polyunsaturated (or omega-3) fatty acid content in the form of docosahexaenoic acid and its importance for brain development, shellfish and aquatic food sources in general are thought to have been important in human brain expansion and evolution (e.g., Brenna and Carlson 2014; Cunnane and Crawford 2014; Joordens et al. 2014; Kyriacou et al. 2014). With regard to nutritional ecology, Hockett and Haws (2003; Haws and Hockett 2004) suggest that broader 
and nutritionally rich diets increase hominid fitness, aid to reduce child mortality, and inter-birth intervals. This in turn, would allow for population increase as for example the increase in population density thought to coincide with the start of the UP (e.g., Mellars and French 2011; French 2015).

Most of the above-mentioned essential nutrients can also be obtained in reasonable quantities through the consumption of animal organs and/or plant foods, with the possible exceptions of vitamins $D$ and omega-3 fatty acids, which are more difficult to obtain from other, terrestrial, sources. However, due to their limited visibility in the archaeological record, it is often hard to assess the role that organ meat and plant foods played in hominin diets. Whereas shellfish are convenient 'food packages', providing an array of essential nutrients not combined in other food sources and, if available, are ideal to assess the nutritional breadth of the diet. Here we use oxygen isotope analysis as a tool to determine the nature and seasonal timing of UP shellfish exploitation. Seasonality of shellfish exploitation data, derived from oxygen isotope analysis, allow us to explore questions about whether coastal environments were used as a supplementary resource in lean times, or if they occupied a more central-place in past foraging strategies and accessed throughout the year. We further investigate whether shellfish gathering was a result of intensification of food resources with increased residency and or population pressure (e.g., Stiner et al. 2013; Marean 2014) through comparisons with exploitation patterns of other faunal resources.

Moreover, data on the periodicity of mollusc collection are helpful for gaining a fuller understanding of coastal foraging strategies (e.g., Mannino et al. 2007, 2014; Colonese et al. 2009; Prendergast et al. 2016) and allow us to address questions regarding behavioural ecology. For example, how prehistoric hunter-gatherers moved in the landscape or how they used their surroundings for raw material procurement (e.g., bivalves of Glycymeris sp. for the manufacture of utilitarian objects or perforated shells for personal ornamentation) or foraging. In addition, these data can be used as a proxy for the timing of site occupation (e.g., Shackleton 1973; Mannino et al. 2011). Here we investigate seasonality of shellfish exploitation by modern humans in the eastern Mediterranean UP using the Ksâr 'Akil (Lebanon) shell assemblage as a case study. To do this we conducted oxygen isotope analysis of the most common edible marine mollusc, Phorcus turbinatus. These data on coastal foraging are complemented with broader patterns of faunal resource and habitat exploitation.

\section{Ksâr 'Akil and its palaeoenvironmental setting}

The Ksâr 'Akil rockshelter is situated close to the eastern Mediterranean coast, approximately $10 \mathrm{~km}$ north of Beirut, Lebanon (Fig. 1). Its multilayered sequence is $23 \mathrm{~m}$ deep and spans the Middle Palaeolithic (MP) to the Epipalaeolithic (EPI) (e.g., Ewing 1947; Mellars and Tixier 1989). It yielded several human fossils (Ewing 1960; Bergman and Stinger 1989; Tillier and Tixier 1991) that are associated with rich archaeological assemblages (Fig. 2). Virtually all mollusc remains were found in UP deposits (van Regteren Altena 1962; Inizan and Gaillard 1978). The UP sequence at Ksâr 'Akil comprises roughly the upper $16 \mathrm{~m}$ of sediments. In this study, the sequence is subdivided following the division in archaeological layers by Williams and Bergman (2010; see also Tixier and Inizan 1981; Azoury 1986; Marks and Volkman 1986; Bergman and Goring-Morris 1987; Kersten 1987; Bergman 1988; Bergman 
and Stinger 1989; Mellars and Tixier 1989; Ohnuma and Bergman 1990; Douka et al. 2013; Leder 2014; Bosch et al. 2015a). Calibrated age estimates (after Bosch et al. 2015a; see also Mellars and Tixier 1989; Douka et al. 2013; 2015; Bosch et al. 2015b) are provided at the $68.2 \%$ probability level. The lowermost UP Layers XXV-XXI comprise so-called Initial Upper Palaeolithic (IUP) assemblages sensu Kuhn et al. (1999), and date to at least 44,600-43,000 cal BP, however the base (i.e., Layers XXV-XXIV) of the IUP remains undated, due to lack of shells or other datable materials from those layers. The IUP is followed by the Early Upper Palaeolithic (EUP) or early Ahmarian deposits (Layers XX-XIV) dating to 43,30042,800 cal BP. These are overlain by two "unnamed UP phases" (Layers XI-XIII and IX-X, respectively) sensu Williams and Bergman (2010) the lithic assemblages of which show both early Ahmarian and (Levantine) Aurignacian affinities. These two phases are grouped into a broader "UP", because of the lack of consensus over their archaeological attribution (e.g., Bergman and Goring-Morris 1987; Williams and Bergman 2010). The subsequent Layers VIII-VII are classic (Levantine) Aurignacian and together with the two previous "unnamed UP" phases, this part of the sequence dates between 41,900 and 32,800 cal BP. Layer VI has been attributed to the Atlitian by Williams and Bergman (2010) and has an age range of 32,700-31,900 cal BP. The top Layers V-I have been described as Epipalaeolithic. The lowest of these layers (i.e., Layer V) is dated to 30,200-29,700 cal BP and a reassessment of the lithics may be prudent in relation to this date.

Ksâr 'Akil is located about $3 \mathrm{~km}$ from the present-day coast, on the northern limestone slope of the Antelias Valley at an elevation of approximately $80 \mathrm{~m}$ above sea level (Ewing 1947; Wright 1962). In prehistoric times, the south-facing rockshelter would have been protected by a hill in the centre of the valley that was quarried away in historic times (Bergman et al. 2012). From the site, hunter-gatherers would have had access to a range of different landscapes, from the mostly rocky shores of the Bay of St. George and its small coastal plain to the steep slopes of the Lebanon Mountains; the top of the mountain range leads to the open highlands of the El Beqaa Valley. Freshwater was available from the stream running down the Antelias Valley and presumably from local springs (Ewing 1947).

The recovered faunal assemblage includes both terrestrial and aquatic molluscs, as well as terrestrial vertebrates (including avian, microfaunal, and macrofaunal taxa) and provides us with additional information on the available habitats surrounding Ksâr 'Akil (Table 1).

The occurrence of terrestrial snails suggests that there were wooded (e.g., Buliminus labrosus, Pene syriacus, Cristataria porrecta, and Helix pachya) as well as open- to half-shaded habitats (e.g., Pomatias elegans, P. olivieri, Oxychilus syriacus, Metafructicola berytensis, Monacha nummus, and M. syriaca) in the vicinity of the site (Bosch et al. 2015c). Freshwater molluscs are rare and comprise Theodoxus jordani, Melanopsis buccinoidea, and Potamida littoralis. The latter adapted to lower-energy regimes (i.e., slow-flowing and /or stagnant water bodies). There is no brackish water component among the assemblage. A bivalve fragment (RGM- 639547) thought to belong to Cerastoderma glaucum was misidentified and is actually a juvenile of Acanthocardia tuberculata (Bosch et al. 2015c). Additionally, marine intertidal rocky shore, soft and hard substrate subtidal taxa were recovered (van Regteren Altena 1962; Bosch et al. 2015c). Taphonomic signatures on the shells suggest that most marine taxa, 
excluding those from intertidal rocky shores, were collected as beached specimens, either from active beaches or from fossil beach deposits.

Avian taxa, studied by Kersten (1991), include open woodland (e.g., Sturnus vulgaris, Columba palumbus, and Turdus sp.), forest (e.g., Garrulus gladarius / Pica pica), rocky country (e.g., Bubo bubo, Gyps fulvus, Aegypius monachus, Aquila cf. chrysaetos, Alectoris chukar, and Columba livia/oenas), aquatic (e.g., Phalacrocorax pygmaeus, Cygnus sp., Anas platyrhynchos, Anser sp. / Branta sp., and Anas sp.), and perhaps open grassland (e.g., cf. Otis tarda and Anser sp. / Branta sp.) species. The occurrence of aquatic birds suggests the presence of standing or slow-flowing freshwater bodies with adjacent marshy or swampy areas, although most of the taxa are known as winter guests, which at that time of the year are also known to frequent brackish or saltwater habitats (Kersten 1991). No human modifications were found on the bird remains and it, therefore, is uncertain whether the accumulation of bird bones resulted from the activity of animal predators or humans. Microfaunal remains, also studied by Kersten (1992), are extremely rare in the UP assemblages and only include the forest dweller, Sciurus anomalus, and the woodland taxon Erinaceus europaeus.

The vertebrate macrofauna includes a mix of open (e.g., Gazella cf. dorcas and Capra aegagrus), open woodland (e.g., Bos sp, Cervus elaphus, and Dama mesopotamica), and forest (e.g., Sus scrofa and Capreolus capreolus) taxa (Hoojier 1961; Bosch et al. 2015a). Thus, the combined faunal assemblages confirm the presence of forests, open woodlands, grasslands or steppes, rocky terrain, freshwater bodies, estuaries/lagoons, and marine habitats in proximity to the rockshelter.

Additionally, anthropogenically-modified mammalian and mollusc remains allow us to make inferences on the habitat types that were exploited by the prehistoric occupants of the site (Table 1 bold). These data suggest that a mix of open (e.g., Gazella cf. dorcas and Capra aegagrus), open woodland (e.g., Bos sp, Cervus elaphus, and Dama mesopotamica), and forest (e.g., Sus scrofa and Capreolus capreolus) habitats were exploited throughout the occupation of the site, whereas steeper rocky terrain (e.g., Capra ibex) and intertidal marine rocky shores (e.g., Phorcus turbinatus, Ph. articulatus, Patella. caerulea, $P$. rustica, and $P$. ulyssiponensis) started to be used from the upper layers of the IUP onward (see also Hooijer 1961; Kersten 1987; Bosch et al. 2015a, 2015c). Here we focus on UP coastal adaptations and, specifically, the exploitation of intertidal rocky shore molluscs by the hunter-gatherers who occupied Ksâr 'Akil.

\section{Materials and Methods}

\subsection{The Ksâr 'Akil mollusc assemblage}

The excavations of the 1930s and 1940s were the only ones to explore the entire archaeological sequence of Ksâr 'Akil. To get an overview of mollusc exploitation from the earliest IUP through the Epipalaeolithic, it was thus necessary to study the mollusc assemblages of these initial excavation campaigns. These included both the molluscs originally described by van Regteren Altena (1962) and recently discovered material found during the study of the vertebrate faunal assemblage in the Naturalis 
collections (Bosch et al. 2015c). All shell samples are currently housed th the department of Fossil Mollusca at Naturalis Biodiversity Center, Leiden.

Regression analyses indicate that both shell completeness (i.e., interdependence after Grayson 1984) and sample size do not differ significantly between layers, suggesting that a chronological evaluation of the material is warranted (Bosch et al. 2015c). The assemblage under study is consistent with preliminary data published by Ewing $(1947,1948,1949)$ indicating that the collection did not suffer extensively from post-excavation loss of material or, at least, that this did not majorly alter the composition of the assemblage.

Unfortunately, different datum points were used in the various excavation seasons, making it difficult to correlate the recovered assemblages (Williams and Bergman 2010). The provenience data further differed per square. Some squares were labelled with the layer, square, and depth below datum, whereas for others only square and depth below datum were provided. Lists based on notes of the original excavators that provide depths per square were used to link the assemblages (Kersten, personal communication 2010; Hooijer 1961; Kersten 1991). Based on lithic studies, Williams and Bergman (2010) suggest that layers from the 1940s excavations correlate with deeper layers of the 1930s excavations probably due to geological sloping processes. The correlation based on the above-mentioned lists indeed shows a certain amount of sloping from the wall of the rockshelter toward the Antelias Valley, indicating that the excavators were aware of this situation and with these lists attempted to correct the

offset. However, the studied material comes from old excavations, which inevitably introduces a level of uncertainty regarding find provenance. As a result of these issues, the oxygen isotope data have been grouped in broader archaeological phases, taking the excavation year into account to overcome the potential problems mentioned by Williams and Bergman (2010).

\subsection{Sample selection}

The intertidal gastropod Phorcus turbinatus was chosen as a proxy to investigate the seasonality of shellfish exploitation, because it is the most abundant marine mollusc species collected for human consumption in the Ksâr 'Akil assemblage (Bosch et al. 2015c). In addition, the physiology of Ph. turbinatus, a fully marine gastropod with low tolerance for temperature and salinity changes (e.g., Schifano and Censi 1983), makes it an ideal taxon to investigate sea surface temperatures (SST). It avoids locations where major fluctuations in salinity occur and lives in the lower inter-tidal zone that is regularly flushed out by tidal action (Mannino et al. 2008), even though such action would be relatively minor within the Mediterranean Basin. When salinity levels are stable, $\delta^{18} \mathrm{O}$ values in shell carbonates can provide information about past SST (e.g., Epstein et al. 1951, 1953; Lécuyer et al. 2004). Moreover, for a species to be a good palaeoclimatic indicator, it should grow year-round and deposit measurable amounts of material in each season (Shackleton 1973). Unfortunately, we have not been able to carry out a modern validation study to ascertain whether Ph. turbinatus from the shores surrounding Ksâr 'Akil can be used as a reliable, seasonally resolved, SST proxy, due to the current political unrest in the area. However, several modern validation studies have been undertaken on living specimens of $P h$. turbinatus populations in the Central and Eastern Mediterranean Sea (e.g., Schifano and Censi 1983; Mannino et al. 2008; Colonese et al. 2009; Prendergast et al. 2013, 2016). These studies show that Ph. turbinatus shell carbonate $\delta^{18} \mathrm{O}$ compositions are strongly negatively correlated to SST and can, 
therefore, be used to study the seasonality of shellfish exploitation by prehistoric humans. Similar validation studies have recently been conducted for members of the genus Patella (Fenger et al. 2007; Surge et al. 2013; Prendergast and Schöne 2017; Gutiérrez-Zugasti et al. 2017), suggesting they are equally suited as paleo-SST indicators and the season of collection of a few Patella spp. specimens from our material was also included in the discussion.

An important prerequisite for obtaining biogenic isotope data, essential for the accurate estimation of season of collection, is that shell carbonates have not been subject to significant pre- or postdepositional diagenesis and recrystallization (e.g., Mannino et al. 2003). If this were the case, isotopic exchanges may have affected the shells, resulting in incorrect estimations of seasonality of shellfish exploitation. Phorcus turbinatus specimens were selected for analysis based on state of preservation and size (and thus age) following Mannino et al. (2008). Only Ph. turbinatus specimens in which the aragonitic layer resembled most that of living specimens, which is generally translucent and, as typical of nacreous microstructures, characterized by iridescent mother-of-pearl were selected. In fact, Milano et al. (2016) recently investigated the effects of exposure to heat on Ph. turbinatus shell microstructure. They found that in shells that were boiled, no significant change in structure or chemistry occurred. Shells that were roasted began to show changes in chemistry and structure only above $300^{\circ} \mathrm{C}$ and these changes were also visible by the naked eye. The shells in our study all preserved the mother of pearl appearance and following Milano et al. (2016) should have endured no significant chemical alteration. This implies that the specimens analysed in our study probably yielded biogenic values useful for an accurate estimation of season of death. Care was also taken to select shells with intact aperture edges and without any growth defects in the form of repair of ante-mortem damage or marked stops in growth parallel to the aperture edge.

To assess preservation, a selection of shells was cross-sectioned and stained with Feigl's solution, to test if the aragonite of the inner shell layer (i.e. the one sampled for isotopic analyses) had been subject to diagenesis. X-ray diffraction was also conducted on selected specimens to verify whether the internal layer was aragonitic and, thus, not affected by diagenesis. Shells were ground into a fine powder with a mortar and pestle and passed through a $90 \mu \mathrm{m}$ sieve. Approximately $0.1 \mathrm{mg}$ was loaded onto a Si low background sample holder. All data were collected in Bragg-Brentano geometry on a D8 Bruker diffractometer equipped with a primary Ge monochromator for $\mathrm{Cu}$ Ka1 and a Sol-X solid state detector. Collection conditions were: $20-60^{\circ}$ in $2 \theta, 0.02$ step size, 4 seconds/step, divergence slits $0.2 \mathrm{~mm}$, receiving slit $0.2 \mathrm{~mm}$, sample spinner on. Rietveld refinements were performed with software Topas 4.1. Aragonite and calcite crystal structures were retrieved from the Crystallographic Open Database (http://www.crystallography.net/cod/) and from the Inorganic Crystal Structure Database (https://cds.dl.ac.uk) respectively. The March-Dollase model for preferred orientation was applied on the following crystal planes: $\left(\begin{array}{llll}0 & 0 & 1\end{array}\right)$ and $\left(\begin{array}{lll}1 & 0 & 0\end{array}\right)$ for aragonite; $\left(\begin{array}{lll}1 & 0 & 4\end{array}\right)$ for calcite. No structural parameter was refined. Peak shapes of all phases were modelled using Pseudo-Voigt functions. Further, Raman spectroscopy to determine the composition of the shell carbonates was carried out on several shells using a Horiba Jobin Yvon LabRam 800 spectrometer equipped with Olympus BX41 optical microscope (University of Mainz). It employed a $532.21 \mathrm{~nm}$ laser wavelength, a $400 \mu \mathrm{m}$ confocal hole, a grating with 1800 grooves $/ \mathrm{mm}$, an entrance slit width of $100 \mu \mathrm{m}$, and $50 \times$ long-distance objective lens. The data 
were acquired with a time window between 3 and 5 seconds. For each sample, two measurements were taken in each shell layer. Furthermore, amino acid racemization (AAR) was conducted on three to five specimens per layer to verify the extent of intracrystalline protein diagenesis and to detect potentially compromised samples (see Penkman et al. 2008; Demarchi et al. 2015).

\subsection{Methodology for deriving season of collection}

In this study, we adopt the approach to establish seasonality of Phorcus lineatus collection originally proposed by Mannino et al. (2003) and further developed and adapted to Ph. turbinatus by Mannino et al. $(2007,2011,2014)$ and other authors (e.g., Colonese et al. 2009; Prendergast et al. 2016). According to this method, applying oxygen isotope analyses to assess past seasonality of shellfish gathering requires, first of all, to establish the range of isotope ratios, which reflects the yearly temperature range, for each archaeological phase under study. We have therefore, sampled at least one specimen per archaeological layer $(n=11)$, to obtain a long sequence of samples that ideally should cover a year of growth. In all cases, except one (KSAS12XX; 15 samples), we drilled 30 calcium carbonate samples or more (up to 40), starting from the edge of the aperture and continuing along the periphery of the shell. This is the axis of maximum growth and it is, therefore, the part of the shell where sampling can attain the highest resolution to establish the full annual range of $\delta^{18} \mathrm{O}$ values (e.g., Mannino et al. 2008). The ranges obtained were then divided into quarters, which are assumed to be roughly equivalent to seasonal $\delta^{18} \mathrm{O}$ ranges. For the layers in which more than one long sequence was sampled, the one with the widest $\delta^{18} \mathrm{O}$ range was used as a baseline to compare edge values of short sequences. As $\delta^{18} \mathrm{O}$ values are negatively correlated with SST, the lowest quarter corresponds to the warmest phase of the year (defined as 'summer') and the highest quarter corresponds to the coldest phase of the year (defined as 'winter'). The two intermediate quarters comprise warming and cooling phases, respectively 'spring' and 'autumn'.

The second step in the approach proposed by Mannino et al. (2003, 2007, 2011, 2014), requires drilling three or more samples from the edge backwards, along the periphery of the shell of as many individuals possible. These samples are used to infer season of death. For specimens in which the last growth increment (i.e., from the edge of the aperture) falls into the intermediate quarters, the trend from the final three $\delta^{18} \mathrm{O}$ values was considered to infer a 'warming' phase (defined as spring), when the values decreased, or a 'cooling' phase (defined as autumn), when the values increased. Specimens were assigned a season (e.g., summer or autumn) when their edge values are $>0.2 \%$ (i.e., measurement error) from a boundary between two quarters. Others, of which the $\delta^{18} \mathrm{O}$ value fell within the range of the measurement error of a boundary between two quarters, were assigned to intermediate categories (e.g., late winter to early spring). SSTs were estimated using the aragonite-temperature equation proposed by Grossman and Ku (1986) with a conversion of VSMOW (used for $\delta^{18} \mathrm{O}_{\text {water }}$ values) to VPDB by Dettman et al. (1999) and taking into account a correction for the glacial conditions in MIS3 of $1.2 \%$ after Paul et al. (2001; see also Prendergast 2016).

\subsection{Sample preparation and isotope analyses}

First, the shells were cleaned using a combination of sonication with purified water and mechanical cleaning using a rounded $10 \mathrm{~mm}$ drillbit. After which, the outer calcareous layer of the shell was 
removed creating a groove and exposing the translucent inner nacreous layer, as proposed by Mannino et al. $(2003,2007,2008)$. We focus on the inner nacreous layer for oxygen isotope analysis for two main reasons: 1 ) to avoid potential diagenetically altered material, which is likely more extensive in the outer prismatic layer and 2) because diagenetic alterations are more easily detectable in the aragonitic part of the shell (Kato et al. 2003; Mannino et al. 2003; Milano et al. 2016). Samples of carbonate powder (approximately $100 \mu \mathrm{g}$ ) were taken from the groove exposing the inner nacreous layer using a $0.5 \mathrm{~mm}$ drill bit. Care was taken to sample at equal depth of roughly $0.8 \mathrm{~mm}$ intervals along the maximum axis of growth starting at the midpoint of the aperture and continuing along the body whorl. In addition, final growth increment $\delta^{18} \mathrm{O}$ analysis was carried out on additional shells $(n=28)$ by taking three sequential samples from the shell's aperture along the periphery of the shell to represent the last growth. The quarters derived from the 'long' sequences, described above, then served as a baseline to infer season of death of other shells from the same archaeological phase for which only 'short' sequences $(n=3)$ were taken. This approach optimizes the number of shells that can be studied and, thereby, the amount of data on past human foraging patterns. In addition, this sampling scheme allows us to obtain accurate season of collection estimations without seriously compromising the morphology of the shells. Taken together, both long and short sequences were used to provide information on the seasonality of shellfish exploitation in the UP at Ksâr 'Akil.

Oxygen and carbon isotope measurements were undertaken at the Godwin Laboratory for Palaeoclimatic Research, University of Cambridge. Carbonate samples were transferred to exetainer vials and sealed with silicone rubber septa using a screw cap. The samples were flushed with CP grade helium, then acidified, left to react for $1 \mathrm{~h}$ at $70^{\circ} \mathrm{C}$ and then analysed using a Thermo Gasbench preparation system attached to a Thermo MAT 253 mass spectrometer in continuous flow mode. Each run of samples was accompanied by 10 reference carbonates (Carrara Z) and two control samples (Fletton Clay). Carrara Z has been calibrated to the Vienna Pee Dee Belemite (VPDB) using the international standard NBS19. Results are reported in delta units $(\delta)$ in parts per mil (\%o) with reference to the international VPDB standard and the precision is better than $\pm 0.08 \%$ ofor $\delta^{13} \mathrm{C}$ and $\pm 0.10 \%$ for $\delta^{18} \mathrm{O}$. Although discussion of $\delta^{13} \mathrm{C}$ is beyond the scope of this paper, it is worth to note that generally,

$\delta^{13} \mathrm{C}$ sequences are cyclic and negatively correlated with $\delta^{18} \mathrm{O}$ (Figs. 3 and 4), suggesting a seasonal influence on variability of $\delta^{13} \mathrm{C}$ as well as in $\delta^{18} \mathrm{O}$ in Ph. turbinatus (see also Mannino et al. 2008).

\section{Results}

\subsection{Marine shellfish exploitation}

The taxa exploited for dietary purposes include the intertidal rocky shore taxa Patella caerulea, $P$. rustica, P. ulyssiponensis, Phorcus turbinatus, and Ph. articulatus, as well as the terrestrial mollusc Helix pachya (Table 2). The marine gastropods were collected live from intertidal rocky shores. The most common species, Ph. turbinatus, first occurs in the IUP Layer XXII. During the EUP Ph. turbinatus was the most frequently-exploited taxon. In Layers XVII and XVI there was a small increase in the frequency of all three Patella species, whereas the proportion of the terrestrial mollusc $-H$. pachya - starts to increase in 
the later phases of the UP. Overall, mollusc exploitation can be characterised by an ever-increasing diversity among the edible species paralleled with terrestrial mollusc exploitation gaining in importance over time.

The anthropogenic origin of the assemblage is evident from the intentional removal of the apices of $P h$. turbinatus to aid shellfish extraction and from the frequent edge damage on Patella spp. congruent with prying the animals off the rocks. Zooarchaeological investigations show a shift in Phorcus processing from apex removal being the norm during the EUP and start of the UP, but becoming gradually less frequent towards the (Levantine) Aurignacian and later periods (Table 3). Edge damage on Patella occurs in about half (i.e., 49.7\%) of the specimens including fragments (Table 3). This frequency increases to $66 \%$ if only (semi) complete shells are considered. Patella are harder to detach from the rocky substrate than Phorcus, which explains the frequent edge damage on the former genus (although some edge damage can also be the result of post-depositional breakage), although this is unlikely to have been a factor limiting Patella exploitation.

\subsection{Oxygen isotope data}

Long sequences obtained for Phorcus turbinatus generally show sinusoidal patterns reflecting annual temperature cycles (Figs. 3 and 4). All specimens, with the possible exception of KSAS06XVII highlighted below, have clearly visible high and low $\delta^{18} \mathrm{O}$ peaks showing annual minima and maxima and cover annual $\delta^{18} \mathrm{O}$ variation. Three specimens (i.e., KSAS02XI, KSASXVI02, and KSASXVI03) show more than one annual cycle. In all instances, for each layer all samples of the long sequence were used to calculate the annual range of $\delta^{18} \mathrm{O}$ variation, which implies that some ranges cover more than one year of growth. Overall, mean $\delta^{18} \mathrm{O}$ values show a slight increase over time indicating a decrease in temperature from the EUP to the Epipalaeolithic (Table 4). Excluding KSAS06XVII, which might not represent a yearly cycle, annual ranges obtained from long sequences span between $2.01 \%$ and $3.35 \%$ representing annual SST variations of $\sim 9^{\circ} \mathrm{C}$ and $\sim 15^{\circ} \mathrm{C}$.

\subsubsection{Seasonality in the Early Upper Palaeolithic (Layers XX - XVI)}

Seasonality data was obtained for $16 \mathrm{Ph}$. turbinatus specimens comprising seven long (Table 4) and nine short sequences (Table 5). For Layer XX a sequence of 15 samples (KSAS12XX) was obtained comprising both a cold and a warm temperature extreme and hence capturing an annual cycle (Fig. $3 \mathrm{~g}$ ). The $\delta^{18} \mathrm{O}$ values increase towards the edge falling in the upper intermediate quarter, suggesting late-autumn or early winter collection. The three edge samples of KSASO4XIX (Layer XIX) show low $\delta^{18}$ O values ranging from $0.83 \%$ o to $0.90 \%$. In comparison with the long sequences from both adjacent layers this suggests the specimen died in summer.

For Layer XVII two long sequences and four short sequences were obtained (Table 5). Final growth analysis suggests late autumn to early winter (KSAS06XVII) and late winter to early spring (KSASXVII02) collection for the long-sequences and winter collection for all four short-sequences (KSASXVII03 to KSASXVII06). Three of the latter specimens display edge values that extend beyond the upper range of $\delta^{18} \mathrm{O}$ variation of the long sequence KSASXVIIO2 (Fig. 5), although they were found in the same layer and square as KSASXVII02. This might suggest the accumulation of the deposit lasted long enough to include shells from slightly different temperature regimes. A certain time-depth in the formation of deposits, is 
to be expected in archaeological assemblages covering several hundreds of years. However, this might introduce a level of uncertainty in accurately determining season of collection.

Lastly, for Layer XVI four long and four short sequences were obtained (Table 5; Figure 6.2). The range of $\delta^{18} \mathrm{O}$ values was largest in the long sequence of KSASXVI02, namely $0.15 \%$ - $2.68 \%$, and encompasses the ranges of the other three long sequences (Table 4); it was therefore used to determine the quarters. The majority of the samples lack clear trends in $\delta^{18} \mathrm{O}$ values of the three edge samples. Among the longsequences, two (KSASO7XVI and KSASXVI02) were collected in late winter or early spring whereas the other two (KSAS10XVI and KSASXVI03) were collected in winter. The edge samples of all shortsequences fall in the intermediate quarters and were collected in autumn (KSASXVI06), probably spring (KSASXVI05), and undetermined either in autumn or spring (KSASXVI01 and KSASXVI04).

\subsubsection{Seasonality in the Upper Palaeolithic (Layers XII - X)}

Phorcus turbinatus not only becomes increasingly rare throughout the UP, but recovered shells also tend to be less well-preserved in terms of, e.g., translucence of the aragonitic layer and presence of mother of pearl. Almost no shells of this species were found in the (Levantine) Aurignacian Layers VIII and VII. In total eight specimens were sampled, comprising one long sequence from Layer XI (Fig. 4) and seven short sequences from Layers XII, XI, X-XI, and X. The $\delta^{18} \mathrm{O}$ values of the edge samples of long sequence (KSASO2XI) suggest that this specimen was collected in late autumn or early winter (Table 4). Final growth analysis of the additional UP specimens suggests summer (KSAS11XII), autumn (KSASXI03), late autumn to early winter (KSASX02 and KSASX-XI01), winter (KSASXI02), spring (KSASX01), and probably spring (KSAKXI01) exploitation (Table 5).

\subsubsection{Seasonality in the Atlitian (Layer VI)}

For the Atlitian Layer $\mathrm{VI}$, one long sequence and six short sequences were obtained. Increasing $\delta^{18} \mathrm{O}$ values towards aperture suggest late autumn to early winter collection for the long sequence KSAS08VI. The additional six short sequences yielded a relatively narrow range of $\delta^{18} \mathrm{O}$ values (i.e., 35\% of the long sequence variation), falling in the cold to intermediate part of the long sequence. These data suggest that shellfish exploitation in the Atlitian was quite restricted to between autumn and early winter.

\subsubsection{Seasonality in the Epipalaeolithic (Layer V)}

One long sequence (KSAS01V) and seven short sequences (KSASV01 to KSASV07) were obtained for Layer $\mathrm{V}$ (Fig. 7). The $\delta^{18} \mathrm{O}$ value of the edge sample clearly falls in the upper or cold quarter pointing to winter collection. Evaluation of trends in $\delta^{18} \mathrm{O}$ variation of the short sequences points to winter (KSASV04 and KSASV05), late spring to early summer (KSASV02 and KSASV07), summer (KSASV06), autumn (KSASV01), and either spring or autumn collection (KSASV03).

\section{Discussion}

Our zooarchaeological and oxygen isotope data suggest that throughout the EUP to EPI occupations at Ksâr 'Akil shellfish were exploited mainly during the colder part of the year, but occasionally also in the warmer and intermediate seasons. Further, there was a shift in Phorcus processing during the UP when removing the apex of the shells for flesh extraction was gradually abandoned. This raises a number of 
discussion points with regards to shellfish exploitation from a local and regional perspective, as well as from a nutritional ecology viewpoint. Below we first place our seasonality of shellfish exploitation data in the broader context of subsistence strategies throughout the occupation of Ksâr 'Akil. We then, review contextual data on shellfish exploitation from the Eastern Mediterranean Palaeolithic, before discussing the dietary and behavioural implications from a human evolutionary perspective.

\subsection{The role of shellfish exploitation in subsistence at Ksâr 'Akil}

\subsubsection{Initial Upper Palaeolithic}

During the earliest stages of the IUP, only beached marine mollusc shells were transported to Ksâr 'Akil, possibly as raw material for tools and ornaments (Layers XXIV and XXIII). Edible taxa, namely Phorcus turbinatus, first occur in the IUP Layer XXII. A Ph. turbinatus specimen from this layer was radiocarbon dated to $\sim 40.6 \mathrm{ka}$ uncal BP, which results in a calibrated age range of 44.1-43.3 ka cal BP (Bosch et al. 2015a). No human modifications were identified on this fragmented specimen and, if it had been taken back to the rockshelter for consumption, it suggests that shellfish exploitation was a marginal activity for the IUP occupants of Ksâr 'Akil. More broadly, subsistence strategies in the IUP seem to have targeted all available terrestrial habitats around the site (i.e., steep rocky country, forests, open woodlands, steppes and/or grasslands). Although coastal marine habitats seem to have been exploited occasionally, there is no evidence for the exploitation of freshwater and/or brackish water habitats (Table 1).

\subsubsection{Early Upper Palaeolithic}

Edible molluscs were consumed more regularly during the EUP than in the IUP. Over $90 \%$ of the Ph. turbinatus shells are devoid of their apex, which is probably mainly ascribable to processing by humans for the extraction of the molluscan flesh (Bosch et al. 2015c). The oxygen isotope data suggest that shellfish exploitation was most commonly practised in the colder months, as is especially evident in Layer XVII, in which all shells seem to have been collected during the winter. For the earlier part of the EUP the data are scarce, but evidence from both long and short sequences suggests that overall shellfish were collected throughout the year, including in warmer months. One of the authors, ALP, is conducting further oxygen isotope analysis on Patella. Preliminary season of collection data suggest late-autumn to early winter collection of a Patella from layer XVI (included in Fig. 6: white).

Compared to the IUP, subsistence behaviour was more diversified during the EUP. Both the inclusion of edible marine and, potentially, of terrestrial molluscs (i.e., Helix pachya) and the increase in taxonomic evenness suggest that the EUP occupants of Ksâr 'Akil had a more varied diet than their IUP predecessors. This is also evident from the more evenly distributed vertebrate faunal assemblages indicating that a wider range of terrestrial animals was part of the diet on a regular basis (Bosch et al. 2015a). Additionally, fresh (avian and molluscs) and perhaps brackish (avian) water species became part of the assemblages (van Regteren Altena 1962; Kersten 1991; Bosch et al. 2015c). However, none of these remains bear clear traces of human modification, and it is therefore unclear if these types of aquatic habitats were actually exploited by the EUP occupants of Ksâr 'Akil for subsistence purposes.

Thus, contrary to the IUP, during the EUP foraging strategies included the regular exploitation of coastal habitats at different times of the year, but with most common collection activities during the colder 
months. The fact that molluscs were collected and taken back to the site in all seasons in turn, implies that Ksâr 'Akil was inhabited throughout the year, albeit not necessarily continuously. The observed pattern of site occupation could have been either part of a residential mobility strategy, involving seasonal changes of base camp, or alternatively occupation at Ksâr 'Akil could have involved logistical mobility, characterized by extended habitation episodes spanning multiple seasons (sensu Binford 1980).

\subsubsection{Upper Palaeolithic}

The proportion of terrestrial molluscs within the edible taxa increases throughout the UP sequence, in parallel with the increasing diversity of marine species. The UP Layers XIII to VII are further characterised by a gradual change in shellfish processing, in which apex removal of Phorcus turbinatus shells decreased. This trend coincides with an increasing importance of $H$. pachya and with a consistent increase in Phorcus size. The extraction of Phorcus flesh is possible without removing the apex, if boiling has successfully broken or damaged the muscle attachment between the flesh and the shell and if 'pinlike' implements were used (e.g., Hill et al. 2015). Cooking the animals at temperatures below $300^{\circ} \mathrm{C}$ would not have left visible traces on the mollusc shells or have biased the oxygen isotope measurements (Milano et al. 2016). For Patella flesh extraction does not require any special processing, once the initial difficulty of prying the animals loose from the rocks is overcome (Fa 2008). These differences in edible mollusc composition and method of shellfish extraction seem to be part of a gradual change in collection and processing strategies throughout the UP rather than representing an abrupt change. However, our data suggest that the seasonality of shellfish exploitation did not change during this period (Fig. 7:1). Preliminary oxygen isotope data on Patella caerulea from the (Levantine) Aurignacian (Layer VII) at Ksâr 'Akil contribute to this picture suggesting winter (RGM- 606363) and late winter to early spring (RGM- 606370) collection.

Recent and ongoing faunal investigations of the vertebrate assemblages have resulted in the identification of Capra ibex in the IUP and EUP deposits among the caprid remains that were previously identified solely to $C$. aegagrus. For the IUP and EUP, human modifications (e.g., cutmarks and impact fractures) on ibex remains attest to human exploitation of steep rocky uplands for subsistence purposes (Bosch et al. 2015a). It is presently unclear if there are also ibex among the caprid remains in the UP, Atlitian and, EPI layers, and it is thus unclear whether, in these periods, steep rocky terrain was exploited for subsistence purposes. Further, UP habitat exploitation is similar to EUP exploitation.

\subsubsection{Atlitian}

The Atlitian mollusc assemblage is diverse in terms of edible taxa and, similarly to the underlying (Levantine) Aurignacian assemblages, dominated by terrestrial molluscs. All Patella display edge damage, whereas only $8.7 \%$ of the Phorcus shells had their apices removed. Further, there are a few freshwater molluscs among the invertebrates, although the assemblage mostly consists of edible marine and terrestrial taxa.

Seasonality of Phorcus exploitation is restricted to autumn and late autumn to winter (Fig. 7.3). Two Patella rustica (both RGM-606376) from the Atlitian have been collected in winter and late winter to early spring. These data confirm that mollusc collection took place in the colder part of the year, albeit 
less restricted in terms of seasonally than evidenced by the Phorcus data alone. The reduction in seasonality could either be an indication of a more restricted period of site occupation and of residential mobility or it could imply a shift in subsistence strategy, with shellfish exploited seasonally despite yearround site occupation. Evaluation of the seasonality of terrestrial animal exploitation could potentially help to solve this question. In addition to the intertidal coastal zone, exploited habitats included forests, open woodlands, and steppes or grasslands. Contrary to the EUP and UP, there are no indicators of freshwater or brackish water among the Atlitian fauna.

\subsubsection{Epipalaeolithic}

The Epipalaeolithic mollusc assemblage is almost entirely composed of edible species, with fluctuating marine and terrestrial proportions. Shellfish exploitation was less restricted seasonally compared to the Atlitian, including collection episodes both in colder (i.e., autumn and winter) and warmer (i.e., late spring to early summer and summer) conditions (Fig. 7:4). These data are complemented by season of collection data of three Patella rustica (all: RGM-606377) from Layer V two of which were collected in winter and one in summer, indicating that for the first time, a larger proportion of shellfish collection occurred in the warm part of the year.

The vertebrate assemblage shows a shift in ungulate exploitation from Layer V to IV. Overall, the vertebrate fauna is dominated by $D$. mesopotamica, followed by $C$. aegagrus and $C$. capreolus (Hooijer 1961). However, the relative abundance of the former taxon increases at the expense of the latter two taxa in Layer IV with respect to Layer V (Kersten 1987). Despite this increase in taxonomic dominance in the vertebrate fauna, the same locally-available environments, continued to be exploited by the Epipalaeolithic inhabitants of the rock shelter.

\subsection{Coastal exploitation in a Mediterranean context}

Not much is known about the seasonality of mollusc collection for the eastern Mediterranean Palaeolithic. In the following section evidence for the exploitation of coastal habitats in the eastern part of the Mediterranean (roughly east from Italy-Libya, see Fig. 1) is presented in chronological order. There is no evidence for shellfish exploitation during the Middle Palaeolithic at Ksâr 'Akil, although this is attested from other Eastern Mediterranean sites (for a summary see Colonese et al. 2011). For example, at Üçağızlı II in Turkey (Stiner 2010), shellfish may have been exploited during the Middle Palaeolithic. Shellfish were also gathered for subsistence purposes by the so-called 'pre-Aurignacian' Middle Palaeolithic occupants of Haua Fteah in Libya; although the Mousterian groups who occupied the same site did not take marine molluscs back to the cave (Klein and Scott 1986; Barker et al. 2012; Hill et al. 2015).

For both the IUP and EUP occupations at Ksâr 'Akil, the site of Üçağızlı I provides us with a good comparative framework for the interpretation of coastal subsistence patterns. Üçağızlı I with its rich IUP and EUP deposits is very similar to Ksâr 'Akil in terms of its lithic technology (Kuhn et al. 2001, 2009) and shellfish exploitation seems to have been practiced in a similar way (Kuhn et al., 2009; Stiner, 2010; Stiner et al. 2013; Bosch et al. 2015c). The IUP invertebrate assemblages of Üçağızlı I comprise beachcollected marine shells, probably used as raw material for tools and ornaments, similarly as at Ksâr 'Akil. 
At both sites, shellfish gathering for dietary purposes started in the second half of the IUP, but only became a regular practice from the EUP onwards (Stiner 2010; Bosch et al. 2015c). For Üçağızlı I there is no data available on the seasonality of shellfish collection, but seasonality data derived from terrestrial fauna seem to suggest that the site was inhabited in autumn and late winter based on the intensity of marrow extraction, and not in late spring and early summer, based on the absence of foetuses and fawns (Stiner 2010). Whereas analysis of seasonality data on the terrestrial fauna of Ksâr 'Akil is in progress, our oxygen isotope data suggest that, similarly to Üçağızlı I, Ksâr 'Akil was occupied by Palaeolithic hunter-gatherers mainly in late autumn and winter, albeit also visited at other times of the year. Lieberman (1993) has argued that this pattern, which he calls a 'radiating' or logistic (sensu Binford 1980) mobility pattern is rare in the southern Levantine UP. He argues that this mobility pattern is inherently unstable in most environments due to the risk of resource depletion and that it has only been recorded in (non-trading) modern-day hunter-gatherers living in rich environments such as what he calls 'marine' habitats or sites located in proximity to multiple exploitable habitats. Although it is hard, if not impossible, to make any statements on regional mobility patterns based on seasonality of exploitation of a single taxon let alone from a single site, both these conditions are met at Ksâr 'Akil and could well explain why it seems to have been sustainable in this instance.

From the UP shellfish exploitation has been reported at Riparo Mochi (Italy). High proportions of edible taxa are reported in (Proto-) Aurignacian deposits reaching up to roughly $60-70 \%$ of the total mollusc assemblage (Stiner 1999). In the eastern Mediterranean, shellfish have further been found in the early UP layers of Klissoura Cave (Greece), for which the intensity of exploitation has been suggested to relate to increased occupation intensity (Stiner et al. 2012). The mollusc assemblages from the slightly more recent UP and EPI deposits of Franchthi Cave (Greece) were thought to attest fluctuating proportions of molluscan taxa, as a result of changing sea levels and subsequent changes in the proximity of the site to the coast (Stiner and Munro 2011; Stiner et al. 2012). However, a recent study by Perlès (2016) has shown that the exploitation of fish, edible molluscs, and ornamental species are in fact independent from each other which suggests that marine resource exploitation was not correlated to sea level variations. Moreover, shells of edible taxa are occasionally found at sites farther from the coast, for example in the Aurignacian deposits of Manot Cave (Israel), attesting that shellfish were part of the diet, but no quantitative data is available on the scale of this subsistence activity (Hershkovitz et al. 2015). At other sites, such as in the Aurignacian layers of Hayonim Cave (Israel), the marine mollusc assemblage comprises only beached shells used as ornaments (Belfer-Cohen and Bar-Yosef 1981) suggesting that coastal habitats were used (either directly or via social exchange networks) by hunter-gatherers living further from the coast, albeit not necessarily for subsistence purposes.

During the Epipalaeolithic and later periods at Haua Fteah (Libya), shellfish exploitation intensified with increasing evidence for overexploitation (Hunt et al. 2011). Oxygen isotope analysis on Phorcus turbinatus indicates that shellfish exploitation was practised in all seasons in the Oranian (around 15-13 ka cal BP), but shifted to mainly winter gathering in the subsequent Capsian and Neolithic (Prendergast et al. 2016). These data correspond well with winter shellfish exploitation patterns of other (early) Holocene sites in the northern Mediterranean (e.g., Colonese et al. 2009; Mannino et al. 2007, 2011, 2014). 


\subsection{Implications of shellfish exploitation for UP Levantine hunter-gatherer}

\section{groups}

Intertidal marine molluscs are easily acquired predictable resource available year-round (e.g., Shackleton and van Andel 1986; Kyriacou et al. 2014; Marean 2014; Jerardino 2016). Due to this predictability, shellfish are thought to have been fall-back resources to tap into during times of resource stress (e.g., Meehan 1977; Waselkov 1987). In the eastern Mediterranean for example, at Haua Fteah during the Capsian and Neolithic intertidal marine molluscs were predominantly gathered in winter, whereas seasonality data for terrestrial fauna indicates that hunting was practiced mainly during the summer, leading Prendergast et al. (2016) to suggest that shellfish were dietary supplements at times of resource depression. For Ksâr 'Akil, investigations on the seasonality of terrestrial fauna exploitation are in progress, therefore patterns in shellfish exploitation and hunting strategies can at present not be compared. However, our oxygen isotope data suggest that, although shellfish exploitation seems to have been restricted to the colder months during the accumulation of some layers (e.g., Layers XVII and $\mathrm{VI}$ ), in general shellfish were collected during different seasons. Previously published biometric data (Bosch et al. 2015c) do not show any evidence for long-term depletion and over-exploitation (e.g., Mannino and Thomas 2002; Fa 2008) of intertidal rocky shore edible taxa. This in turn suggests that shellfish, perhaps accompanied by terrestrial molluscs, could have been a regular food supplement for the occupants of Ksâr 'Akil from the EUP onwards.

Intensified use of coastal resources is often taken to be an indicator of reduced residential mobility and / or population pressure (e.g., Stiner et al. 1999; Stiner 2001; Finlayson et al. 2006; Fa 2008; Steele and Klein 2013; Marean 2014; Prendergast et al. 2016). Moreover, it has been argued, on the basis of the broad spectrum revolution hypothesis (MacArthur and Pianka 1966), that increased population density can be seen in the archaeological record by a diversification in exploited faunal taxa. However, due to the low carrying capacity of eastern Mediterranean coasts, it is unlikely that the exploitation of intertidal rocky shore molluscs alone could have supported a substantial population increase. For the eastern Mediterranean, increased dietary breadth, and especially the inclusion of small-bodied fast-moving taxa (such as birds and hare), has been documented for the Upper Palaeolithic (e.g., Stiner 2001, 2010). At Ksâr 'Akil no dietary diversification is evident in the IUP and - similarly to what is attested by the MP deposits - faunal exploitation focused on few species, namely Dama mesopotamica, Capra aegagrus, and Sus scrofa. Moreover, shellfish exploitation seems to have occurred on a low level at the end of the IUP, but there is no evidence that these resources were exploited by the earliest anatomically modern humans who occupied the site (i.e., at the time of the modern human fossil named "Ethelruda", recovered in Layer XXV). In the EUP, however, broadening of the diet is reflected in the increased taxonomic evenness of hunted vertebrates, the increase in the number of habitats exploited for subsistence purposes, as well as in the regular consumption of both shellfish and terrestrial molluscs into the diet. A similar pattern in shellfish exploitation has been documented at the roughly contemporary site of Üçağızlı I (Stiner 2010). Taken together, this evidence suggests there was an increasing strain on resources in the northeastern Mediterranean coastal zone during the EUP. In turn, this evidence for resource depression may be indicative of an increased population density. 
To determine if shellfish exploitation at Ksâr 'Akil can be interpreted as a coastal adaptation first the definition of a 'coastal adaptation' should be explored. Marean (2014; see also Jerardino 2016) argues that the exploitation of coastal habitats should be a central part of subsistence and mobility strategies and marine foods should form a substantial part of the diet. In the eastern Mediterranean coastal resources were exploited since at least MIS 5 (Stiner 2010; Colonese et al. 2011), but this does not equate to a fully developed coastal adaptation. Archaeological proxies such as the ratio between terrestrial fauna and marine molluscs, comparing taxonomic diversity, shell sizes, and shell density have been used to identify intensity of shellfish exploitation in UP contexts (e.g., Steele and Klein 2009; Jerardino and Marean 2010; Stiner 2010; Stiner and Munro 2011; Langejans et al. 2012; Clark and Kandel 2013; Perlès 2016). It is hard to identify a full coastal adaptation in terms of Marean's (2014) criteria at Ksâr 'Akil given the low productivity (in terms of caloric value) of the eastern Mediterranean coastal zone. There is however ample evidence of regular exploitation of coastal habitats. Our data suggest that the importance of shellfish gathering steadily increased from the IUP to the EPI. However, there is no evidence for long-term overharvesting of these coastal resources at any time, nor could we detect any trends in taxonomic diversity of molluscs. Our seasonality data contribute to this picture by showing that shellfish exploitation occurred throughout the year, and, although there seems to be an emphasis on the colder months, it was not a seasonally restricted activity. In other words, coastal habitats were frequented increasingly often and intertidal molluscs would have been regularly included in hunter-gatherer subsistence strategies. Albeit, with the possible exception of the Atlitian, during which coastal exploitation could only be demonstrated from autumn to early spring. Thus, our data do not support the classification of a full coastal adaptation sensu Marean (2014), they do however, attests of the regular use of coastal habitats from the EUP onward.

Shellfish consumption was probably advantageous both in terms of macro (protein) and micro (essential nutrients) acquisition. From a nutritional ecology perspective, the regular intake of essential nutrients including vitamins $A, B 12, C, D, E$, iron, folate, potassium, calcium, and omega-3 fatty acids would have been especially beneficial. Several body functions and systems require these essential nutrients for example the immune system (Vitamin A), blood formation and oxygen transport (B12 and iron), bone mineralisation ( $D$ and calcium), collagen synthesis and wound healing $(C)$, the nervous system (B12 and $E)$, heart function (Potassium), muscle and body growth ( $A$ and $E$ ), vision (A), and brain function (B12, E, folate, and omega-3 fatty acids). Folate and omega-3 fatty acids are thought to be especially important in fetal and infant brain development (e.g, Brenna and Carlson 2014; Cunnane and Crawford 2014). Hockett and Haws (2003; Haws and Hockett 2004) suggest that broader and nutritionally rich diets increase hominin fitness, contribute to reduce child mortality and inter-birth intervals. Thus, huntergatherers that regularly ingest a wide range of essential nutrients would have a better position to compete with groups that have less balanced diets. It has been argued that women are likely to have had less access than men to nutritiously rich terrestrial resources, such as organ meat and brains, as these tissues decay swiftly and the bulk would have been eaten immediately by the hunters (Parkington 2003). However, especially pregnant women and children require more omega-3 fatty acids and quality nutrition in general. In modern hunter-gatherers, shellfish are mainly gathered by women and children providing them access to the much-needed essential nutrients (e.g., Meehan 1982). Our data suggest 
that at Ksâr 'Akil shellfish exploitation indeed occupied a central place in hunter-gatherer foraging strategies from the EUP onward rather than being restricted to certain times of the year.

\section{Conclusions}

At Ksâr 'Akil shellfish exploitation is first attested in the upper layers of the IUP, albeit in low quantities. From the EUP onwards shellfish exploitation played a more important role in hunter-gatherer foraging strategies, given that it was practised in each season, with an emphasis on winter collection. During the UP, shellfish were also collected in every season, but the focus was more on late autumn to winter and spring. The Atlitian witnessed a short-lived reduction in seasonality of shellfish exploitation, in which marine molluscs seem only to have been gathered in the colder months (i.e., from autumn to early spring). With the start of the EPI, in Layer V, shellfish were again gathered throughout the year and were for the first time more frequently gathered in the warmer part of the year (i.e., late spring to early summer and summer). Although some layers show more restricted gathering episodes, overall shellfish exploitation seems not to have been seasonally restricted.

When the seasonality data is taken as a proxy for site occupation, it appears that hunter-gatherers occupied Ksâr 'Akil during different times of the year, although perhaps not continuously. This pattern could either be explained through the existence of a residential mobility strategy, which would have seen hunter-gatherer groups returning to the site in different seasons, or of a logistical mobility strategy, which would have entailed occupation periods lasting multiple seasons. Moreover, Layers XVII and VI show temporally more restricted exploitation that could either be indicative of shorter periods of site occupation, or if people were present they did not always gather shellfish and/or bring them to the rockshelter. Seasonality of terrestrial fauna exploitation, as an alternative proxy for site-occupation, could help answer this question.

The more regular inclusion of coastal marine resources from the EUP onwards signifies a broadening of the human diet, which is also reflected in the number of exploited habitats, by the more evenly distributed exploitation of mammals and by the inclusion of edible terrestrial molluscs. Overall, this suggests hunter-gatherer groups tried to optimize their strategies to exploit fuller the carrying capacity of their immediate surroundings. This in turn may indicate an increase in population density along the eastern Mediterranean coast in the EUP and later periods compared to the IUP. In addition to merely broadening animal resource exploitation, the regular consumption of shellfish was likely beneficial for past hunter-gatherer diets, considering it provided them with essential nutrients otherwise not available in the terrestrial foods that constituted the main component of the diet. According to nutritional ecology theory (e.g., Hocket and Haws 2003), the regular ingestion of these nutritionally rich molluscs would have resulted in improved fitness. This, in turn, could have contributed, along with a range of other resources, to an increase in population density that characterizes the Early Upper Palaeolithic record.

In the wider regional setting, marine resources (particularly intertidal gastropods) seem to have been consistently exploited in the Levantine coastal zone. In the future, the data presented here should be contextualised with seasonality data on terrestrial fauna exploitation from Ksâr 'Akil. This would serve to 
broaden our knowledge on seasonal activities at the site and provide a better view on the full extent of site-occupation and timing of resource exploitation. These data, in turn, should be compared with seasonality data from other Levantine sites (e.g., Lieberman 1993), allowing evaluation of subsistence and mobility strategies of past hunter-gatherers on a broader regional scale.

\section{Acknowledgements}

MDB would like to thank Laura Niven, Shannon McPherron, Ronald Pouwer, Beatrice Demarchi, Hans van der Plicht, Alexander Verpoorte, Mary Stiner, Natalie Munro, Daniella Bar-Yosef Mayer and Philip Nigst for useful discussions. In addition, we would like to thank two anonymous reviewers for their time and feedback which improved our manuscript.

Funding: H2020 Marie Skłodowska-Curie fellowship "EU-BEADS", project number: 656325 and the Max Planck Society. ALP was funded by an Alexander von Humboldt Postdoctoral Fellowship.

Author contributions: MDB and MAM designed the research; MDB, ALP and MAM performed analyses; $M D B$, wrote the paper with input from all authors.

\section{References}

Avery, G., Halkett, D., Orton, J., Steele, T., Tusenius, M., Klein, R., 2008. The Ysterfontein 1 Middle Stone Age rock shelter and the evolution of coastal foraging. South African Archaeological Society Goodwin Series 10, 66-89.

Azoury, I., 1986. Ksar Akil, Lebanon: A technological and typological analysis of the transitional and early Upper Palaeolithic Levels of Ksar Akil and Abu Halka. BAR International Series BAR, Oxford.

Barker, G., Bennett, P., Farr, L., Hill, E., Hunt, C., Lucarini, G., Morales, J., Mutri, G., Prendergast, A., Pryor, A., 2012. The Cyrenaican Prehistory Project 2012: the fifth season of investigations of the Haua Fteah cave. Libyan Studies 43, 115-136.

Belfer-Cohen, A., Bar-Yosef, O., 1981. The Aurignacian at Hayonim Cave. Paléorient 7 (2), 19-42.

Bergman, C.A., 1988. Ksar Akil and the upper palaeolithic of the Levant. Paléorient 14 (2), 201-210.

Bergman, C.A., Goring-Morris, A.N., 1987. Conference: The Levantine Aurignacian with special reference to Ksar Akil, Lebanon March 27-28, 1987 Institute of Archaeology, London. Paléorient 13 (1), 142-147.

Bergman, C.A., Stinger, C.B., 1989. Fifty years after: Egbert, an early upper Palaeolithic juvenile from Ksar Akil, Lebanon. Paléorient 16 (2), 99-111.

Bergman, C., Azoury, I., Seeden, H., 2012. Ksas Aqil At the crossroads Out of Africa. Saudi Aramco World $63(5), 1-7$.

Binford, L.R., 1980. Willow Smoke and Dogs' Tails: Hunter-Gatherer Settlement Systems and Archaeological Site Formation. American Antiquity 45 (1), 4-20. 
Bosch, M.D., Mannino, M.A., Prendergast, A.L., OConnell, T.C., Demarchi, B., Taylor, S.M., Niven, L., van der Plicht, J., Hublin, J.-J., 2015a. New chronology for Ksâr Akil (Lebanon) supports Levantine route of modern human dispersal into Europe. Proceedings of the National Academy of Sciences 112 (25), 768-7688.

Bosch, M.D., Mannino, M.A., Prendergast, A.L., OConnell, T.C., Demarchi, B., Taylor, S.M., Niven, L., van der Plicht, J., Hublin, J.-J., 2015b. Reply to Douka et al.: Critical evaluation of the Ksâr'Akil chronologies. Proceedings of the National Academy of Sciences 112 (51), E7035-E7035.

Bosch, M.D., Wesselingh, F.P., Mannino, M.A., 2015c. The Ksâr'Akil (Lebanon) mollusc assemblage: Zooarchaeological and taphonomic investigations. Quaternary International 390, 85-101.

Braun, D.R., Harris, J.W.K., Levin, N.E., McCoy, J.T., Herries, A.I.R., Bamford, M.K., Bishop, L.C., Richmond, B.G., and Kibunjia, M., 2010. Early hominin diet included diverse terrestrial and aquatic animals $1.95 \mathrm{Ma}$ in East Turkana, Kenya. Proceedings of the National Academy of Sciences 107 (22), 10002-10007.

Brenna, J.T., Carlson, S.E., 2014. Docosahexaenoic acid and human brain development: Evidence that a dietary supply is needed for optimal development. Journal of Human Evolution 77, 99-106.

Clark, J.L., Kandel, A.W., 2013. The Evolutionary Implications of Variation in Human Hunting Strategies and Diet Breadth during the Middle Stone Age of Southern Africa. Current Anthropology 54 (S8), S269S287.

Colonese, A.C., Troelstra, S., Ziveri, P., Martini, F., Lo Vetro, D., Tommasini, S., 2009. Mesolithic shellfish exploitation in SW Italy: seasonal evidence from the oxygen isotopic composition of Osilinus turbinatus shells. Journal of Archaeological Science 36 (9) 1935-1944.

Colonese, A.C., Mannino, M.A., Bar-Yosef Mayer, D.E., Fa, D.A., Finlayson, J.C., Lubell, D., Stiner, M.C., 2011. Marine mollusc exploitation in Mediterranean prehistory: An overview. Quaternary International 239 (1-2), 86-103.

Cortés-Sánchez, M., Morales-Muñiz, A., Simón-Vallejo, M.D., Lozano-Francisco, M.C., Vera-Peláez, J.L., Finlayson, C., Rodríguez-Vidal, J., Delgado-Huertas, A., Jiménez-Espejo, F.J., Martínez-Ruiz, F., 2011. Earliest known use of marine resources by Neanderthals. PloS ONE 6 (9), e24026.

Cunnane, S.C., Crawford, M.A., 2014. Energetic and nutritional constraints on infant brain development: Implications for brain expansion during human evolution. Journal of Human Evolution 77, 88-98.

Demarchi, B., Clements, E., Coltorti, M., van de Locht, R., Kröger, R., Penkman, K., Rose, J., 2015. Testing the effect of bleaching on the bivalve Glycymeris: A case study of amino acid geochronology on key Mediterranean raised beach deposits. Quaternary Geochronology 25, 49-65.

Dettman, D.L., Reische, A.K., Lohmann, K.C., 1999. Controls on the stable isotope composition of seasonal growth bands in aragonitic fresh-water bivalves (Unionidae). Geochimica et Cosmochimica Acta 63 (7), 1049-1057. 
Douka, K., Bergman, C.A., Hedges, R.E.M., Wesselingh, F.P., Higham, T., 2013. Chronology of Ksar Akil (Lebanon) and Implications for the Colonization of Europe by Anatomically Modern Humans. PLoS ONE 8 (9), e72931.

Douka, K., Higham, T.F., Bergman, C.A., 2015. Statistical and archaeological errors invalidate the proposed chronology for the site of Ksar Akil. Proceedings of the National Academy of Sciences 112 (51), E7034-E7034.

Emiliani, C., Cardini, L., Mayeda, T., McBurney, C.B.M., Tongiorgi, E., 1964. Palaeotemperature analysis of marine molluscs (food refuse) from the site of Arene Candide cave, Italy and the Haua Fteah cave, Cyrenaica. In: Craig, S., Miller, S.L., Wasserburg, G.J. (Eds.), Isotopic and Cosmic Chemistry. North Holland, Amsterdam, pp. 133-156.

Epstein, S., Buchsbaum, R., Lowenstam, H., Urey, H.C., 1951. Carbonate-water isotopic temperature scale. Geological Society of America Bulletin 62 (4), 417-426.

Epstein, S., Buchsbaum, R., Lowenstam, H.A., Urey, H.C., 1953. Revised carbonate-water isotopic temperature scale. Geological Society of America Bulletin 64 (11), 1315-1326.

Erlandson, J.M., Moss, M.L., 2001. Shellfish Feeders, Carrion Eaters, and the Archaeology of Aquatic Adaptations. American Antiquity 66 (3), 413-432.

Ewing, F.J., 1947. Preliminary note on the excavations at the Palaeolithic site of Ksar'Akil, Republic of Lebanon. Antiquity 21 (84), 186-196.

Ewing, J.F., 1948. Ksar'Akil in 1948. Biblica, 29, 272-278.

Ewing, J.F., 1949. The treasures of Ksar'Akil. Thought 24, 255-288.

Ewing, J.F., 1960. Human types and prehistoric cultures at Ksar'Akil, Lebanon. Men and Cultures: Selected Papers Fifth Int. Congr. Anthrop. Ethnol. Sci. Philadelphia 1956, 535-539.

Fa, D.A., 2008. Effects of tidal amplitude on intertidal resource availability and dispersal pressure in prehistoric human coastal populations: the Mediterranean-Atlantic transition. Quaternary Science Reviews 27 (23), 2194-2209.

Fa, D.A., Finlayson, J.C., Finlayson, G., Giles-Pacheco, F., Rodríguez-Vidal, J., Gutiérrez-López, J.M., 2016. Marine mollusc exploitation as evidenced by the Gorham's Cave (Gibraltar) excavations 1998-2005: The Middle-Upper Palaeolithic transition. Quaternary International 407 Part B, 16-28.

Fenger, T., Surge, D., Schöne, B., Milner, N., 2007. Sclerochronology and geochemical variation in limpet shells (Patella vulgata): a new archive to reconstruct coastal sea surface temperature. Geochemics Geophysics Geosystemics 8, Q07001.

Finlayson, C., Giles Pacheco, F., Rodrıguez-Vidal, J., Fa, D.A., Gutierrez Lo' pez, J.M., Santiago Perez, A., Finlayson, G., Allue , E., Baena Preysler, J., Caceres, I., Carrion, J.S., Ferna'ndez Jalvo, Y., Gleed-Owen, 
C.P., Jimenez Espejo, F., Lopez, P., Lopez Saez, J.A., Riquelme Cantal, J.A., Sanchez Marco, A., Giles Guzman, F., Brown, K., Fuentes, N., Valarino, C.A., Villalpando, A., Stringer, C.B., Martinez Ruiz, F., Sakamoto, T., 2006. Late survival of Neanderthals at the southernmost extreme of Europe. Nature 443, 850-853.

Finlayson, C., Fa, D.A., Espejo, F.J., Carrión, J.S., Finlayson, G., Pacheco, F.G., Vidal, J.R., Stringer, C., Ruiz, F.M., 2008. Gorham's Cave, GibraltarThe persistence of a Neanderthal population. Quaternary International $181(1), 64-71$.

French, J. C., 2015. Demography and the Palaeolithic Archaeological Record." Journal of Archaeological Method and Theory 1-50

Grayson, D. K. 1984. Quantitative Zooarchaeology: Topics in the analysis of archaeological faunas. Orlando: Academic Press.

Grayson, D. K., \& Delpech, F. 1998. Changing diet breadth in the early upper Palaeolithic of southwestern France. Journal of Archaeological Science, 25(11), 1119-1129.

Grossman, E.L., Ku, T.-L., 1986. Oxygen and carbon isotope fractionation in biogenic aragonite: temperature effects. Chemical Geology: Isotope Geoscience section 59, 59-74.

Gutiérrez-Zugasti, I., Suárez-Revilla, R., Clarke, L. J., Bernd R. Schöne, B. R., Geoffrey N. Bailey, G. N., González-Morales, M. R. 2017. Shell oxygen isotope values and sclerochronology of the limpet Patella vulgata Linnaeus 1758 from northern Iberia: Implications for the reconstruction of past seawater temperatures. Palaeogeography Palaeoclimatology Palaeoecology.

Haws, J.A., Hockett, B.S., 2004. Theoretical perspectives on the dietary role of small animals in human evolution. Petits Animaux et Societes Humanes. Du Complement Alimentaire aux Resources Utilitaires: 533-544.

Hershkovitz, I., Marder, O., Ayalon, A., Bar-Matthews, M., Yasur, G., Boaretto, E., Caracuta, V., Alex, B., Frumkin, A., Goder-Goldberger, M., Gunz, P., Holloway, R.L., Latimer, B., Lavi, R., Matthews, A., Slon, V., Mayer, D.B., Berna, F., Bar-Oz, G., Yeshurun, R., May, H., Hans, M.G., Weber, G.W., Barzilai, O., 2015. Levantine cranium from Manot Cave (Israel) foreshadows the first European modern humans. Nature 520 (7546), 216-219.

Hill, E.A., Hunt, C.O., Lucarini, G., Mutri, G., Farr, L., Barker, G., 2015. Land gastropod piercing during the Late Pleistocene and Early Holocene in the Haua Fteah, Libya. Journal of Archaeological Science: Reports 4, 320-325.

Hockett, B., Haws, J., 2003. Nutritional ecology and diachronic trends in Paleolithic diet and health. Evolutionary Anthropology: Issues, News, and Reviews 12 (5), 211-216.

Hooijer, D.A., 1961. The fossil vertebrates of Ksar'Akil, a palaeolithic rock shelter in the Lebanon. Zoologische Verhandelingen 49 (1), 1-68. 
Hunt, C.O., Reynolds, T.G., El-Rishi, H.A., Buzaian, A., Hill, E., Barker, G.W., 2011. Resource pressure and environmental change on the North African littoral: Epipalaeolithic to Roman gastropods from Cyrenaica, Libya. Quaternary International 244 (1), 15-26.

Inizan, M.-L., Gaillard, J.M., 1978. Coquillages de Ksar 'Aqil: éléments de parure? Paléorient 4 (1), 295306.

Jerardino, A., 2015. Shell density as proxy for reconstructing prehistoric aquatic resource exploitation, perspectives from southern Africa. Journal of Archaeological Science: Reports 6, 637-644.

Jerardino, A., 2016. On the origins and significance of Pleistocene coastal resource use in southern Africa with particular reference to shellfish gathering. Journal of Anthropological Archaeology 41, 213-230.

Jerardino, A., Marean, C.W., 2010. Shellfish gathering, marine paleoecology and modern human behavior: perspectives from cave PP13B, Pinnacle Point, South Africa. Journal of Human Evolution 59 (34), 412-424.

Joordens, J.C., d'Errico, F., Wesselingh, F.P., Munro, S., de Vos, J., Wallinga, J., Ankjærgaard, C., Reimann, T., Wijbrans, J.R., Kuiper, K.F., Mücher, H.J., Coqueugniot, H., Prié, V., Joosten, I., van Os, B., Schulp, A.S., Panuel, M., van der Haas, V., Lustenhouwer, W., Reijmer, J.J., Roebroeks, W., 2014. Homo erectus at Trinil on Java used shells for tool production and engraving. Nature 518, 228-231.

Kato, K., Wada, H., Fujioka, K., 2003. The application of chemical staining to separate calcite and aragonite minerals for micro-scale isotopic analyses. Geochemical Journal 37 (2), 291-297.

Kersten, A.M.P., 1987. Age and sex composition of Epipalaeolithic fallow deer and wild goat from Ksar'Akil. Palaeohistoria 29, 119-131.

Kersten, A.M., 1991. Birds from the Palaeolithic rock shelter of Ksar'Akil, Lebanon. Paléorient 17 (2), 99116.

Kersten, A.M., 1992. Rodents and Insectivores from the Palaeolithic Rock Shelter of Ksar'Akil (Lebanon) and their palaeoecological Implications. Paléorient 18 (1), 27-45.

Klein, R.G., Scott, K., 1986. Re-analysis of faunal assemblages from the Haua Fteah and other Late Quaternary archaeological sites in Cyrenaican Libya. Journal of Archaeological Science 13 (6), 515-542.

Klein, R.G., Avery, G., Cruz-Uribe, K., Halkett, D., Parkington, J.E., Steele, T., Volman, T.P., Yates, R., 2004. The Ysterfontein 1 Middle Stone Age site, South Africa, and early human exploitation of coastal resources. Proceedings of the National Academy of Sciences of the United States of America 101 (16), 5708-5715.

Kuhn, S.L., Stiner, M.C., Güleç, E., 1999. Initial Upper Palaeolithic in south-central Turkey and its regional context: a preliminary report. Antiquity $73,505-517$. 
Kuhn, S.L., Stiner, M.C., Reese, D.S., Güleç, E., 2001. Ornaments of the earliest Upper Paleolithic: New insights from the Levant. Proceedings of the National Academy of Sciences 98 (13), 7641-7646.

Kuhn, S.L., Stiner, M.C., Güleç, E., Özer, I., Yilmaz, H., Baykara, I., Açikkol, A., Goldberg, P., Molina, K.M., Ünay, E., Suata-Alpasian, F., 2009. The early Upper Paleolithic occupations at Üçağızlı Cave (Hatay, Turkey). Journal of Human Evolution 56, 87-113.

Kyriacou, K., Parkington, J.E., Marais, A.D., Braun, D.R., 2014. Nutrition, modernity and the archaeological record: Coastal resources and nutrition among Middle Stone Age hunter-gatherers on the western Cape coast of South Africa. Journal of Human Evolution 77, 64-73.

Kyriacou, K., Parkington, J.E., Will, M., Kandel, A.W., Conard, N.J., 2015. Middle and Later Stone Age shellfish exploitation strategies and coastal foraging at Hoedjiespunt and Lynch Point, Saldanha Bay, South Africa. Journal of Archaeological Science 57, 197-206.

Langejans, G.H., van Niekerk, K.L., Dusseldorp, G.L., Thackeray, J.F., 2012. Middle Stone Age shellfish exploitation: Potential indications for mass collecting and resource intensification at Blombos Cave and Klasies River, South Africa. Quaternary International 270, 80-94.

Lécuyer, C., Reynard, B., Martineau, F., 2004. Stable isotope fractionation between mollusc shells and marine waters from Martinique Island. Chemical Geology 213, 293-305.

Leder, D., 2014. Technological and Typological Change at the Middle to Upper Palaeolithic Boundary in Lebanon. In: Universitätsforschungen zur prähistorischen Archäologie 255. Habelt Verlag, Bonn.

Lieberman, D.E., 1993. The rise and fall of seasonal mobility among hunter-gathers: The case of the Southern Levant. Current Anthropology 34 (5), 599-631.

MacArthur, R. H., Pianka, E.R., 1966. On optimal use of patchy environment. American Naturalist 100, 603-609.

Mannino, M.A., Thomas, K.D., 2002. Depletion of a resource? The impact of prehistoric human foraging on intertidal mollusc communities and its significance for human settlement, mobility and dispersal. World Archaeology 33 (3), 452-474.

Mannino, M.A., Spiro, B.F., Thomas, K.D., 2003. Sampling shells for seasonality: oxygen isotope analysis on shell carbonates of the inter-tidal gastropod Monodonta lineata (da Costa) from populations across its modern range and from a Mesolithic site in southern Britain. Journal of Archaeological Science 30 (6), 667-679.

Mannino, M.A., Thomas, K.D., Leng, M.J., Piperno, M., Tusa, S., Tagliacozzo, A., 2007. Marine resources in the Mesolithic and Neolithic at the Grotta dell'Uzzo (Sicily): Evidence from isotope analyses of marine shells. Archaeometry 49 (1), 117-133. 
Mannino, M.A., Thomas, K.D., Leng, M.J., Sloane, H.J., 2008. Shell growth and oxygen isotopes in the topshell Osilinus turbinatus: resolving past inshore sea surface temperatures. Geo-Marine Letters 28 (56), 309-325.

Mannino, M.A., Thomas, K.D., Leng, M.J., Di Salvo, R., Richards, M.P., 2011. Stuck to the shore? Investigating prehistoric hunter-gatherer subsistence, mobility and territoriality in a Mediterranean coastal landscape through isotope analyses on marine mollusc shell carbonates and human bone collagen. Quaternary International 244 (1), 88-104.

Mannino, M.A., Thomas, K.D., Crema, E.R., Leng, M.J., 2014. A matter of taste? Mode and periodicity of marine mollusc exploitation on the Mediterranean island of Favignana (Ègadi Islands, Italy) during its isolation in the early Holocene. Archaeometry 23, 133-147.

Marean, C.W., 2014. The origins and significance of coastal resource use in Africa and Western Eurasia. Journal of Human Evolution 77, 17-40.

Marks, A.E., Volkman, P., 1986. The Mousterian of Ksar Akil: levels XXVIA through XXVIIIB. Paléorient 12 (1), 5-20.

Meehan, B., 1977. Man does not live by calories alone: the role of shellfish in coastal cuisine: in Allen J. Golson J. and Jones R. (eds) Sunda and Sahul. Prehistoric Studies in Southeast Asia Melanesia and Australia Academic Press. Maningrida. Blyth River. Arnhem Land. pp. 493-531.

Meehan, B., 1982. Shell bed to shell midden. Aboriginal Studies Press, Canberra.

Mellars, P., French, J. C., 2011. Tenfold Population Increase in Western Europe at the Neandertal-toModern Human Transition. Science, 333:6042, 623-627

Mellars, P., Tixier, J., 1989. Radiocarbon-accelerator dating of Ksar 'Aqil (Lebanon) and the chronology of the Upper Palaeolithic sequence in the Middle East. Antiquity 63, 761-768.

Milano, S., Prendergast, A.L., Schöne, B.R., 2016. Effects of cooking on mollusk shell structure and chemistry: Implications for archeology and paleoenvironmental reconstruction. Journal of Archaeological Science: Reports 7, 14-26.

Ohnuma, K., Bergman, C.A., 1990. A technological analysis of the Upper Palaeolithic levels (XXV-VI) of Ksar Akil, Lebanon. In: P. Mellars (Ed.), The emergence of modern humans: An archaeological perspective. Edinburgh University, Edinburgh, pp. 91-138.

Parkington, J., 2003. Middens and moderns: shellfishing and the Middle Stone Age of the Western Cape, South Africa. South African Journal of Science 99, 243-247.

Paul, H.A., Bernasconi, S.M., Schmid, D.W., McKenzie, J.A., 2001. Oxygen isotopic composition of the Mediterranean Sea since the Last Glacial Maximum: constraints from pore water analyses. Earth and Planetary Science Letters 192 (1), 1-14. 
Perlès, C., 2016. Food and ornaments: Diachronic changes in the exploitation of littoral resources at Franchthi Cave (Argolid, Greece) during the Upper Palaeolithic and the Mesolithic $(39,000 \mathrm{e} 7000 \mathrm{cal}$ BC). Quaternary International 407: 45-58

Penkman, K.E.H., Kaufman, D.S., Maddy, D., Collins, M.J., 2008. Closed-system behaviour of the intracrystalline fraction of amino acids in mollusc shells. Quaternary Geochronology 3 (1), 2-25.

Prendergast, A. L., Schöne, B. R., 2017. Oxygen isotopes from limpet shells: Implications for palaeothermometry and seasonal shellfish foraging studies in the Mediterranean. Palaeogeography, Palaeoclimatology. Palaeoecology. (xxx) 1-15. http://dx.doi.org/10.1016/j.palaeo.2017.03.007

Prendergast, A.L., Azzopardi, M., O'Connell, T.C., Hunt, C., Barker, G., Stevens, R.E., 2013. Oxygen isotopes from Phorcus (Osilinus) turbinatus shells as a proxy for sea surface temperature in the central Mediterranean: A case study from Malta. Chemical Geology, 345: 77-86.

Prendergast, A.L., Stevens, R.E., O'Connell, T.C., Fadlalak, A., Touati, M., al-Mzeine, A., Schöne, B.R., Hunt, C.O., Barker, G., 2016. Changing patterns of eastern Mediterranean shellfish exploitation in the Late Glacial and Early Holocene: Oxygen isotope evidence from gastropod in Epipaleolithic to Neolithic human occupation layers at the Haua Fteah cave, Libya. Quaternary International: 407: 80-93.

Regteren Altena, van, C.O., 1962. Molluscs and Echinoderms from Palaeolithic deposits in the Rock Shelter of Ksâr'Akil, Lebanon. Zoologische Mededelingen 38 (5), 87-99.

Schifano, G., Censi, P., 1983. Oxygen isotope composition and rate of growth of Patella coerulea, Monodonta turbinata and $M$. articulata shells from the western coast of Sicily. Palaeogeography, Palaeoclimatology, Palaeoecology 42 (3), 305-311.

Shackleton, N.J., 1973. Oxygen isotope analysis as a means of determining season of occupation of prehistoric midden sites. Archaeometry 15 (1), 133-141.

Shackleton, J.C., van Andel, T.H., 1986. Prehistoric shore environments, shellfish availability, and shellfish gathering at Franchthi, Greece. Geoarchaeology 1, 127-143.

Steele, T.E., Klein, R.G., 2009. Late Pleictocene Subsistence strategies and resource intensification in Africa. The Evolution of Hominin Diets, Springer 113-126

Steele, T.E., Klein, R.G., 2013. The Middle and Later Stone Age faunal remains from Diepkloof Rock Shelter, Western Cape, South Africa. Journal of Archaeological Science 40 (9), 3453-3462.

Stiner, M.C., 1999. Palaeolithic mollusc exploitation at Riparo Mochi (Balzi Rossi, Italy): food and ornaments from the Aurignacian through Epigravettian. Antiquity 73, 735-754.

Stiner, M.C., 2001. Thirty years on the "broad spectrum revolution" and paleolithic demography. Proceedings of the National Academy of Sciences of the United States of America 98 (13), 6993-6996. 
Stiner, M.C., 2010. Prey choice, site occupation intensity and economic diversity in the Middle-early Upper Palaeolithic at the Üçagizli Caves, Turkey. Before Farming 2009 (3), 1-20.

Stiner, M.C., Munro, N.D., 2011. On the evolution of diet and landscape during the Upper Paleolithic through Mesolithic at Franchthi Cave (Peloponnese, Greece). Journal of Human Evolution 60 (5), 618636.

Stiner, M.C., Munro, N.D., Surovell, T.A., Tchernov, E., Bar-Yosef, O., 1999. Paleolithic Population Growth Pulses Evidenced by Small Animal Exploitation. Science 283, 190-194.

Stiner, M.C., Munro, N.D., Starkovich, B.M., 2012. Material input rates and dietary breadth during the Upper Paleolithic through Mesolithic at Franchthi and Klissoura 1 Caves (Peloponnese, Greece). Quaternary International 275, 30-42.

Stiner, M.C., Kuhn, S.L., Güleç, E., 2013. Early Upper Paleolithic shell beads at Üçağızlı Cave I (Turkey): technology and the socioeconomic context of ornament life-histories. Journal of Human Evolution 64 (5), 380-398.

Surge, D., Wang, T., Gutierrez-Zugasti, I., Kelley, P.H., 2013. Isotope sclerochronology of annual growth line formation in limpet shells (Patella vulgata) from warm and coldtemperate zones in the eastern North Atlantic. PALAIOS 28, 386-393.

Tillier, A.-M., Tixier, J., 1991. Une molaire d'enfant aurignacien à Ksar'Aqil (Liban). Paléorient 17 (1), 8993.

Tixier, J., Inizan, M.-L., 1981. Ksar Aqil, stratigraphie et ensembles lithiques dans le Paléolithique supérieur: fouilles 1971-1975. Préhistoire du Levant: chronologie et organisation de l'espace depuis les origines jusquau Vle millénaire. Colloques Internationaux du CNRS: 10-14.

Waselkov, G.A., 1987. Shellfish gathering and shell midden archaeology. Advances in Archaeological Method and Theory 10, 93-210.

Williams, J.K., Bergman, C.A., 2010. Upper Paleolithic levels XIII-VI (A and B) from the 1937-1938 and 1947-1948 Boston College excavations and the Levantine Aurignacian at Ksar Akil, Lebanon. Paléorient $36(2), 117-161$.

Wright, H.E., 1962. Late Pleistocene geology of coastal Lebanon. Quaternaria 6, 525-539.

\section{Table captions}

Table 1: Habitat diversity (based on various faunal indicators) per archaeological phase. Presence is indicated by a x. Habitats exploited by humans shown in bold. Birds: Kersten 1991; Microfauna: Kersten 1992; Mammals: Hooijer 1961 and this study; molluscs: van Regteren Altena 1962 and Bosch et al. 2015c. Abbreviations: EPI: Epipalaeolithic, UP: Upper Palaeolithic, EUP: Early Upper Palaeolithic, IUP: Initial Upper Palaeolithic, MP: Middle Palaeolithic. 
Table 2: Quantities and proportions of edible molluscs throughout the Ksâr 'Akil sequence. Abbreviations: NISP: number of identifiable specimens, \%: percentage, EPI: Epipalaeolithic, UP: Upper Palaeolithic, EUP: Early Upper Palaeolithic, IUP: Initial Upper Palaeolithic.

Table 3: Anthropogenic modifications on intertidal marine molluscs. Abbreviations: $\mathrm{n}$ : number, $\%$ : percentage, BD: basal diameter, SD: standard deviation, EPI: Epipalaeolithic, UP: Upper Palaeolithic, EUP: Early Upper Palaeolithic, IUP: Initial Upper Palaeolithic.

Table 4: Range of $\delta^{18} \mathrm{O}$ values obtained from 'long' and 'short' sequences. Bold: long sequences used to determine quarters of the annual $\delta^{18} \mathrm{O}$ range per layer. Abbreviations: $\mathrm{BD}$ : basal diameter, $\mathrm{n}$ samples: number of sequential samples, \% range: percentage of the range of $\delta^{18} \mathrm{O}$ values of a layer's long sequence that is covered by the range of $\delta^{18} \mathrm{O}$ values of all edge samples (i.e., representing last growth) of that layer, the value in brackets shows \% range without outlier KSASV06.

Table 5: Season of mollusc collection data per archaeological techno-complex. Abbreviations: ID: lab identification number, RGM-no: museum inventory number, ${ }^{*}$ : samples for which a long-sequence was obtained. Trend: $\uparrow$ : increase in $\delta^{18} O$ value, $\downarrow$ : decrease in $\delta^{18} O$ value, -: no significant (i.e., within machine error) increase or decrease of $\delta^{18} \mathrm{O}$ value. The first symbol in column 'trend' shows change between edge and $2^{\text {nd }}$ value, second symbol in column 'trend' shows change between $2^{\text {nd }}$ and $3^{\text {rd }}$ value. $\sim$ and italic: determination of season of collection based on the trend between the 3rd and edge sample (because the overall trend of the three edge samples was not sufficient to establish season of collection), EPI: Epipalaeolithic, UP: Upper Palaeolithic, EUP: Early Upper Palaeolithic.

\section{Figure captions}

Figure 1: Map of eastern Mediterranean showing location of Ksâr 'Akil and sites discussed in text. 1: Ksâr 'Akil. - 2: Manot. - 3: Hayonim. - 4: Üçağızlı I. - 5: Haua Fteah. - 6: Franchti. - 7: Klissoura. - 8: Riparo Mochi. Digital elevation data originates from the Shuttle Radar Topography Mission (https://Ita.cr.usgs.gov/SRTMBasic), downloaded from USGS Earth Resources Observation and Science (EROS) Center (http://eros.usgs.gov).

Figure 2: Ksâr 'Akil stratigraphy divided in the following phases: EPI: Epipalaeolithic, UP: Upper Palaeolithic, Atlitian, EUP: Early Upper Palaeolithic or Early Ahmarian, IUP: Initial Upper Palaeolithic, MP: Middle Palaeolithic, and the first occurrence of the main mollusc taxa discussed in the text.

Figure 3: $\delta^{18} \mathrm{O}$ and $\delta^{13} \mathrm{C}$ values obtained by sampling long sequences of samples from $P h$. turbinatus shells recovered in EUP contexts: a: KSASO7XVI (Layer XVI), b: KSAS10XVI (Layer XVI), c: KSASXVI02 (Layer XVI), d: KSASXVI03 (Layer XVI), e: KSAS06XVII (Layer XVII), f: KSASXVII02 (Layer XVII), g: KSAS12XX (Layer $X X)$. 
Figure 4: $\delta^{18} \mathrm{O}$ and $\delta^{13} \mathrm{C}$ values obtained by sampling long sequences of samples from $\mathrm{Ph}$. turbinatus shells recovered in UP, Atlitian, and EPI contexts: a: KSAS01V (Layer V), b: KSAS08VI (Layer VI), c: KSAS02XI (Layer XI).

Figure 5: $\delta^{18} \mathrm{O}$ values of edge samples of $P$ h. turbinatus, including (on top) a reference to the range of oxygen isotope values obtained from the long sequences per layer or techno-complex (red: lowest quarter defined as summer, blue: highest quarter defined as winter). 1: Epipalaeolithic, 2: Atlitian, 3: Upper Palaeolithic (Layer XI: black, other UP Layers: grey), and 4: Early Upper Palaeolithic (Layer XVI: black, Layer XVII dark grey, other EUP Layers light grey).

Figure 6: Rose diagrams reporting the season of Ph. turbinatus (per Layer: grey and per Phase: black) and Patella spp. (white) collection. 1: Early Upper Palaeolithic (EUP) comprising Layers XX-XVI, 2: Layer XVI, 3: Layer XVII.

Figure 7: Rose diagrams reporting the season of Ph. turbinatus (per Layer: grey and per Phase: black) and Patella spp. (white) collection. 1: Upper Palaeolithic (UP) comprising Layers XII-VII, 2: Layer XI, 3: Atlitian, 4: Epipalaeolithic (EPI). 


\begin{tabular}{|c|c|c|c|c|c|c|c|c|}
\hline \multirow{6}{*}{ EPI } & habitat & forest & $\begin{array}{c}\text { open } \\
\text { woodland }\end{array}$ & $\begin{array}{l}\text { steppe/ } \\
\text { grassland }\end{array}$ & $\begin{array}{c}\text { steep rocky } \\
\text { country }\end{array}$ & freshwater & brackish & marine \\
\hline & birds & $x$ & $x$ & & $x$ & $x$ & & \\
\hline & micro fauna & & & & & & & \\
\hline & mammals & $x$ & $x$ & $x$ & $(x)$ & & & \\
\hline & molluscs & $x$ & $x$ & & & & & $x$ \\
\hline & all EPI & $x$ & $x$ & $x$ & $x$ & $x$ & & $x$ \\
\hline \multirow{5}{*}{ Atlian } & birds & & & & & & & \\
\hline & micro fauna & & & & & & & \\
\hline & mammals & $x$ & $x$ & $x$ & $(x)$ & & & \\
\hline & molluscs & $x$ & $\mathrm{x}$ & & & $x$ & & $x$ \\
\hline & all Atlian & $x$ & $x$ & $x$ & $(x)$ & $x$ & & $x$ \\
\hline \multirow{5}{*}{ UP } & birds & $x$ & $x$ & $x$ & $x$ & $x$ & & \\
\hline & micro fauna & $x$ & & & & & & \\
\hline & mammals & $x$ & $x$ & $x$ & $(x)$ & & & \\
\hline & molluscs & $x$ & $x$ & & & $x$ & & $x$ \\
\hline & all UP & $x$ & $x$ & $x$ & $x$ & $x$ & & $x$ \\
\hline \multirow{5}{*}{ EUP } & birds & $x$ & $x$ & & $x$ & $x$ & & \\
\hline & micro fauna & & $x$ & & & & & \\
\hline & mammals & $x$ & $x$ & $x$ & $x$ & & & \\
\hline & molluscs & $x$ & $x$ & & & $x$ & $(x)$ & $x$ \\
\hline & all EUP & $x$ & $x$ & $x$ & $x$ & $x$ & $(x)$ & $x$ \\
\hline \multirow{5}{*}{ IUP } & birds & & & & $x$ & & & \\
\hline & micro fauna & & & & & & & \\
\hline & mammals & $x$ & $x$ & $x$ & $x$ & & & \\
\hline & molluscs & $x$ & $x$ & & & & & $(X)$ \\
\hline & all IUP & $x$ & $x$ & $x$ & $x$ & & & $(X)$ \\
\hline \multirow{5}{*}{$\mathrm{MP}$} & birds & $x$ & $x$ & & $x$ & & & \\
\hline & micro fauna & & & & & & & \\
\hline & mammals & $x$ & $x$ & $x$ & & & & \\
\hline & molluscs & & & & & & & $(x)$ \\
\hline & all MP & $x$ & $x$ & $x$ & $x$ & & & $(x)$ \\
\hline
\end{tabular}




\begin{tabular}{|c|c|c|c|c|c|c|c|c|c|c|c|c|}
\hline & layer & $\begin{array}{l}\text { NISP } \\
\text { total }\end{array}$ & $\begin{array}{l}\text { Food } \\
\text { (NISP) }\end{array}$ & $\begin{array}{l}\text { Food } \\
\text { (\%) }\end{array}$ & $\begin{array}{l}\text { Helix } \\
\text { pachya }\end{array}$ & $\begin{array}{l}\text { Patella } \\
\text { caerulae }\end{array}$ & $\begin{array}{l}\text { Patella } \\
\text { rustica }\end{array}$ & $\begin{array}{l}\text { Patella } \\
\text { ulyssiponensis }\end{array}$ & $\begin{array}{l}\text { Patella } \\
\text { sp. }\end{array}$ & $\begin{array}{l}\text { Phorcus } \\
\text { articulatus }\end{array}$ & $\begin{array}{l}\text { Phorcus } \\
\text { turbinatus }\end{array}$ & $\begin{array}{l}\text { Phorcus } \\
\text { sp. }\end{array}$ \\
\hline \multirow{5}{*}{ EPI } & $\mathbf{I}$ & 2 & 2 & 100.00 & 1 & & 1 & & & & & \\
\hline & II & 6 & 3 & 50.00 & 1 & 1 & 1 & & & & & \\
\hline & III & 28 & 28 & 100.00 & 13 & & 1 & & & & 14 & \\
\hline & IV & 22 & 18 & 81.82 & 12 & & & & 1 & & 5 & \\
\hline & $\mathbf{v}$ & 242 & 220 & 90.91 & 80 & 1 & 18 & & 1 & & 120 & \\
\hline Atlitian & VI & 103 & 80 & 77.67 & 42 & 2 & 7 & 2 & 2 & & 25 & \\
\hline \multirow{7}{*}{ UP } & VII & 273 & 195 & 71.43 & 125 & 21 & 6 & 2 & 7 & & 34 & \\
\hline & VIII & 195 & 87 & 44.62 & 64 & 6 & 1 & 2 & 1 & & 13 & \\
\hline & IX & 446 & 52 & 11.66 & 21 & 2 & 3 & & 3 & 1 & 19 & 3 \\
\hline & $x$ & 119 & 34 & 28.57 & 9 & 1 & 3 & & & & 21 & \\
\hline & $\mathbf{X I}$ & 465 & 134 & 28.82 & 21 & 1 & & & 1 & 8 & 43 & 60 \\
\hline & XII & 51 & 14 & 27.45 & 4 & & & & & & 7 & 3 \\
\hline & XIII & 11 & 8 & 72.73 & 1 & & & & & & 7 & \\
\hline \multirow{7}{*}{ EUP } & XIV & 3 & 2 & 66.67 & 2 & & & & & & & \\
\hline & $x V$ & 2 & 0 & 0.00 & & & & & & & & \\
\hline & $\mathbf{X V I}$ & 220 & 64 & 29.09 & 16 & 1 & 9 & 1 & & & 37 & \\
\hline & XVII & 633 & 162 & 25.59 & 44 & 4 & 19 & 1 & 11 & 2 & 71 & 10 \\
\hline & XVIII & 72 & 10 & 13.89 & 2 & & & & 2 & & 6 & \\
\hline & $\mathrm{XIX}$ & 177 & 16 & 9.04 & 8 & & & & & & 7 & 1 \\
\hline & $x x$ & 46 & 3 & 6.52 & & & & & 1 & & 2 & \\
\hline \multirow{4}{*}{ IUP } & XXI & 60 & 2 & 3.33 & 2 & & & & & & & \\
\hline & XXII & 197 & 1 & 0.51 & & & & & & & 1 & \\
\hline & XXIII & 22 & 0 & & & & & & & & & \\
\hline & XXIV & 9 & 0 & & & & & & & & & \\
\hline
\end{tabular}




\begin{tabular}{|c|c|c|c|c|c|c|c|c|}
\hline & \multirow[b]{2}{*}{ layer } & \multicolumn{3}{|c|}{ Patella spp. } & \multicolumn{4}{|c|}{ Phorcus sp. } \\
\hline & & no damage & edge damage (n) & edge damage (\%) & mean BD ( $n ; S D)$ & intact (n) & no apex (n) & no apex (\%) \\
\hline \multirow{5}{*}{ EPI } & $\mathbf{I}$ & & & & & & & \\
\hline & II & 1 & 1 & 50.00 & & & & \\
\hline & III & 0 & 1 & 100 & $24.97(13 ; 2.37)$ & 10 & 2 & 16.67 \\
\hline & IV & 1 & 0 & 0.00 & $26.76(4 ; 2.60)$ & 4 & 1 & 20.00 \\
\hline & $\mathbf{v}$ & 9 & 11 & 55.00 & $25.67(101 ; 2.60)$ & 105 & 1 & 0.94 \\
\hline Atlitian & VI & 0 & 13 & 100 & $26.60(22 ; 1.99)$ & 21 & 2 & 8.70 \\
\hline \multirow{7}{*}{ UP } & VII & 13 & 23 & 63.89 & $26.40(23 ; 2.31)$ & 21 & 3 & 12.50 \\
\hline & VIII & 6 & 4 & 40.00 & $25.32(8 ; 2.87)$ & 7 & 1 & 12.50 \\
\hline & IX & 5 & 3 & 37.50 & $25.50(4 ; 2.46)$ & 4 & 2 & 33.33 \\
\hline & $x$ & 3 & 1 & 25.00 & $25.65(9 ; 2.91)$ & 4 & 6 & 60.00 \\
\hline & $\mathbf{X I}$ & 2 & 0 & 0.00 & $26.07(15 ; 3.10)$ & 2 & 14 & 87.50 \\
\hline & XII & & & & & 0 & 0 & \\
\hline & XIII & & & & $25.14(4 ; 2.36)$ & 1 & 3 & 75.00 \\
\hline \multirow{7}{*}{ EUP } & XIV & & & & & & & \\
\hline & XV & & & & & & & \\
\hline & $\mathrm{XVI}$ & 1 & 10 & 90.91 & $22.69(17 ; 2.08)$ & 1 & 18 & 94.74 \\
\hline & XVII & 29 & 6 & 17.14 & 23.88 (21: 1.99) & 1 & 25 & 96.15 \\
\hline & XVIII & & & & $27.18(2 ; 1.32)$ & 0 & 2 & 100.00 \\
\hline & XIX & & & & & 0 & 0 & \\
\hline & $x x$ & & & & & 0 & 1 & 100.00 \\
\hline
\end{tabular}




\begin{tabular}{|c|c|c|c|c|c|c|c|c|c|c|c|c|c|c|}
\hline \multirow[b]{2}{*}{ Sample ID } & \multirow[b]{2}{*}{ Layer } & \multirow{2}{*}{$\begin{array}{c}\text { BD } \\
(\mathrm{mm})\end{array}$} & \multirow{2}{*}{$\begin{array}{c}n \\
\text { samples }\end{array}$} & \multirow{2}{*}{$\begin{array}{c}{ }^{14} \mathrm{C} \\
\text { (ka cal BP) }\end{array}$} & \multicolumn{3}{|c|}{ long sequence } & \multicolumn{3}{|c|}{ short sequences } & \multicolumn{3}{|c|}{ edge samples } & \multirow[b]{2}{*}{$\%$ range } \\
\hline & & & & & $\min$ & $\max$ & range & $\min$ & $\max$ & range & $\min$ & $\max$ & range & \\
\hline KSAS01V & $\mathbf{v}$ & 23.91 & 40 & $30.2-29.7$ & 1.45 & 3.55 & 2.1 & 0.53 & 3.55 & 3.02 & 0.53 & 3.55 & 3.02 & $>100$ (79) \\
\hline KSAS08VI & VI & 26.84 & 40 & $32.6-31.9$ & 0.77 & 4.07 & 3.30 & 1.17 & 3.36 & 2.25 & 2.19 & 3.36 & 1.17 & 35.45 \\
\hline KSAS02XI & $\mathbf{X I}$ & 25.56 & 39 & $38.7-38.1$ & 0.51 & 3.52 & 3.01 & 0.89 & 3.61 & 2.72 & 1.67 & 3.61 & 1.94 & 64.45 \\
\hline KSAS11XII & XII & - & 5 & $40.3-39.7$ & - & - & - & 0.53 & 0.88 & 0.35 & - & - & - & - \\
\hline KSAS07XVI & $\mathrm{XVI}$ & 21.45 & 32 & $43.5-42.9$ & 0.57 & 2.24 & 1.67 & - & - & - & - & - & - & - \\
\hline KSAS10XVI & $X \mathrm{VI}$ & 22.12 & 35 & $40.4-39.8$ & 0.24 & 2.66 & 2.42 & - & - & - & - & - & - & - \\
\hline KSASXVI02 & XVI & 20.19 & 40 & $41.7-41.2$ & 0.15 & 2.68 & 2.53 & 0.62 & 2.73 & 2.11 & 1.38 & 2.66 & 1.28 & 49.61 \\
\hline KSASXVI03 & $\mathrm{XVI}$ & 22.86 & 30 & $43.4-42.9$ & 0.59 & 2.67 & 2.08 & - & - & - & - & - & - & - \\
\hline KSAS06XVII & XVII & 22.53 & 30 & $43.4-42.8$ & 0.44 & 1.84 & 1.4 & - & - & - & - & - & - & - \\
\hline KSASXVII02 & XVII & 23.06 & 40 & 42.3-41.9 & 0.29 & 2.3 & 2.01 & 1.53 & 2.98 & 1.45 & 1.64 & 2.98 & 1.34 & 66.67 \\
\hline KSAS04XIX & $\mathrm{XIX}$ & - & 3 & $43.1-42.6$ & - & - & - & 0.83 & 0.9 & 0.07 & - & - & - & - \\
\hline KSAS12XX & $X X$ & - & 15 & $43.6-43.0$ & 0.35 & 2.53 & 2.18 & 1.31 & 2.02 & 0.71 & - & - & - & - \\
\hline
\end{tabular}




\begin{tabular}{|c|c|c|c|c|c|c|c|c|c|}
\hline technocomplex & ID & RGM-No. & square & edge & 2nd & 3rd & trend & quarter & season \\
\hline \multirow{8}{*}{ EPI } & KSAS01V* & 606338 & E4-6 & 3.55 & 3.17 & 3.3 & 个 - & cold & winter \\
\hline & KSASV01 & 606338 & E4-6 & 2.56 & 2.69 & 2.17 & $-\uparrow$ & intermediate & autumn \\
\hline & KSASV02 & 606338 & E4-6 & 1.89 & 2.36 & 2.78 & $\downarrow \downarrow$ & warm-intermediate & late spring - early summer \\
\hline & KSASV03 & 606336 & E4-6 & 2.22 & 2.38 & 2.3 & -- & intermediate & spring - autumn \\
\hline & KSASV04 & 606336 & E4-6 & 3.44 & 3.52 & 3.54 & -- & cold & winter \\
\hline & KSASV05 & 606336 & E4-6 & 3.41 & 2.98 & 3.21 & $\uparrow \downarrow$ & cold & winter \\
\hline & KSASV06 & 606336 & E4-6 & 0.53 & 1.6 & 1.15 & $\downarrow \uparrow$ & warm & summer \\
\hline & KSASV07 & 606336 & E4-6 & 1.9 & 2.19 & 2.09 & $\downarrow-$ & warm-intermediate & late spring - early summer \\
\hline \multirow{6}{*}{ Atlian } & KSAS08VI* & 606337 & E4,FG3-4 & 3.36 & 3.05 & 3.01 & 个 - & cold-intermediate & late autumn - early winter \\
\hline & KSASVI01 & 606337 & E4,FG3-4 & 2.19 & 1.63 & 1.25 & 个个 & intermediate & autumn \\
\hline & KSASVI03 & 606337 & E4,FG3-4 & 2.37 & 1.17 & 1.34 & $\uparrow-$ & intermediate & autumn \\
\hline & KSASVI04 & 606337 & E4,FG3-4 & 2.44 & 2.52 & 2.5 & -- & intermediate & spring - autumn \\
\hline & KSASVI06 & 606337 & E4,FG3-4 & 3.24 & 2.32 & 1.9 & 个个 & cold-intermediate & late autumn - early winter \\
\hline & KSASVI07 & 606337 & E4,FG3-4 & 2.53 & 3 & 1.87 & $\downarrow \uparrow$ & intermediate & qutumn \\
\hline \multirow{8}{*}{ UP } & KSASX01 & 606323 & E5 & 1.59 & 1.74 & 2.06 & $-\downarrow$ & intermediate & spring \\
\hline & KSASX02 & 606323 & E5 & 2.66 & 1.78 & 1.51 & 个个 & cold-intermediate & late autumn - early winter \\
\hline & KSASX-XI01 & 606321 & F5 & 2.62 & 1.87 & 1.94 & 个 - & cold-intermediate & late autumn - early winter \\
\hline & KSASO2XI* & 606317 & E5 & 2.96 & 2.2 & 2.27 & 个 - & cold-intermediate & late autumn - early winter \\
\hline & KSASXI01 & 606317 & E5 & 1.67 & 0.89 & 2.36 & $\uparrow \downarrow$ & intermediate & spring \\
\hline & KSASXI02 & 606317 & $\mathrm{E} 5$ & 3.61 & 3.52 & 3.12 & $-\uparrow$ & cold & winter \\
\hline & KSASXI03 & 606311 & E4 & 2.27 & 1.64 & 1.38 & 个个 & intermediate & autumn \\
\hline & KSAS11XII & 606421 & E4 & 0.72 & 0.53 & 0.88 & $-\downarrow$ & warm & summer \\
\hline \multirow{16}{*}{ EUP } & KSAS07XVI* & 606334 & E5 & 1.97 & 1.38 & 2.24 & $\uparrow \downarrow$ & cold-intermediate & late winter - early spring \\
\hline & KSAS10XVI* & 606310 & $\mathrm{~F} 3$ & 2.66 & 2.51 & 2.38 & -- & cold & winter \\
\hline & KSASXVI01 & 606334 & E5 & 1.71 & 1.57 & 1.75 & -- & intermediate & spring - autumn \\
\hline & KSASXVIO2* & 606334 & E5 & 1.53 & 1.51 & 1.62 & -- & intermediate & late winter - early spring \\
\hline & KSASXVI03* & 606334 & E5 & 2.4 & 2.07 & 2.01 & 个 - & cold & winter \\
\hline & KSASXVI04 & 606334 & E5 & 1.82 & 2.73 & 1.84 & $\downarrow \uparrow$ & intermediate & spring - autumn \\
\hline & KSASXVI05 & 606334 & E5 & 1.38 & 2.07 & 1.59 & $\downarrow \uparrow$ & intermediate & spring \\
\hline & KSASXVI06 & 606334 & E5 & 1.67 & 1.13 & 0.62 & 个个 & intermediate & autumn \\
\hline & KSAS06XVII* & 606306 & $\mathrm{~F} 4$ & 1.64 & 1.53 & 1.73 & -- & cold-intermediate & late autumn - early winter \\
\hline & KSASXVIIO2* & 606309 & E4 & 1.69 & 2.3 & 2.21 & $\downarrow-$ & cold-intermediate & late winter - early spring \\
\hline & KSASXVIII03 & 606306 & $\mathrm{~F} 4$ & 2.55 & 2.38 & 2 & $-\uparrow$ & cold & winter \\
\hline & KSASXVIIO4 & 606306 & $\mathrm{~F} 4$ & 2.98 & 2.5 & 2.13 & 个个 & cold & winter \\
\hline & KSASXVIIO5 & 606306 & $\mathrm{~F} 4$ & 2.87 & 2.35 & 2.15 & $\uparrow-$ & cold & winter \\
\hline & KSASXVIIO6 & 606309 & E4 & 1.95 & 1.57 & 1.79 & $\uparrow \downarrow$ & cold & winter \\
\hline & KSASO4XIX & 639387 & F4 & 0.9 & 0.83 & 0.87 & -- & warm & summer \\
\hline & KSAS12XX* & 606294 & F4 & 2.02 & 1.67 & 1.31 & 个个 & cold-intermediate & late autumn - early winter \\
\hline
\end{tabular}




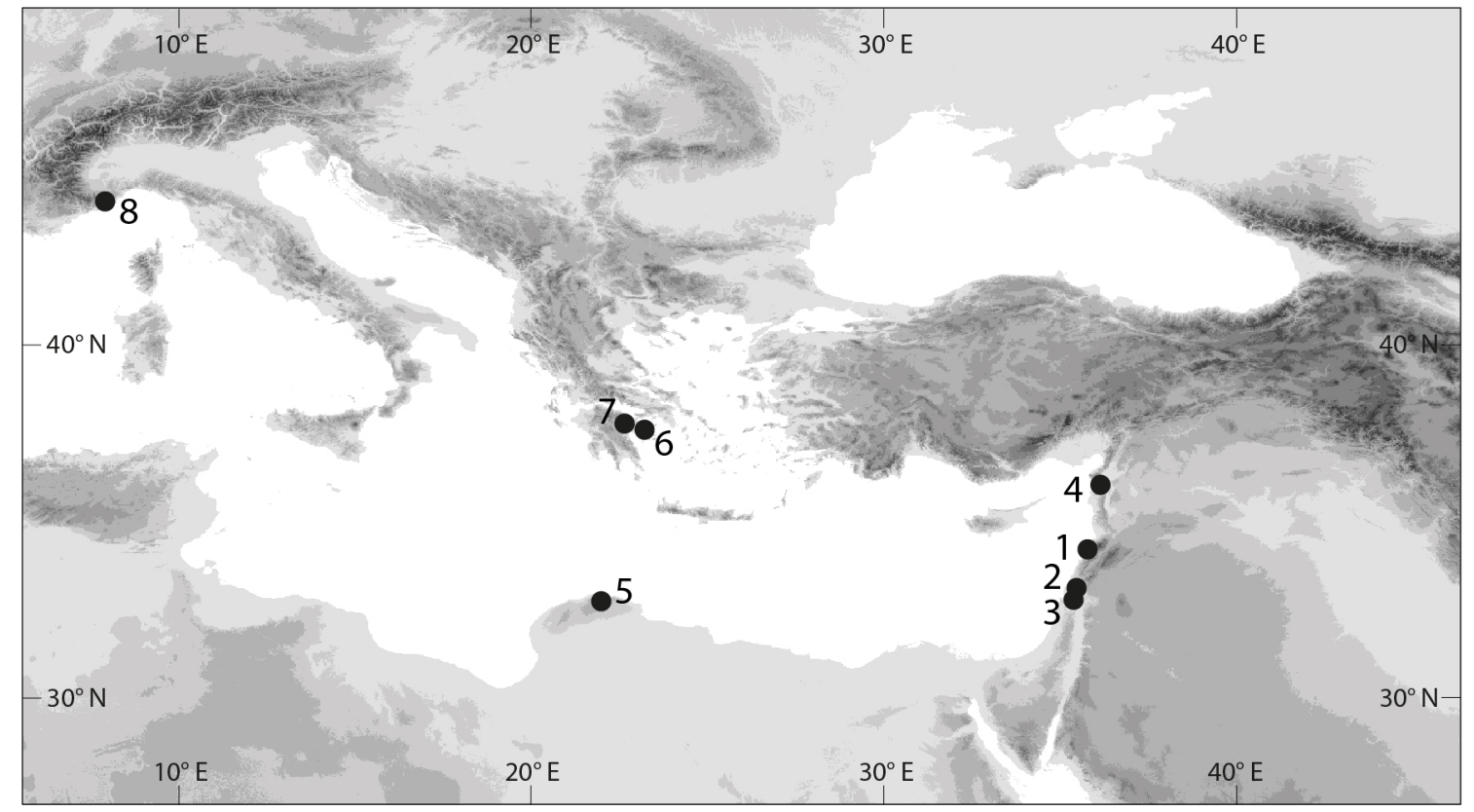




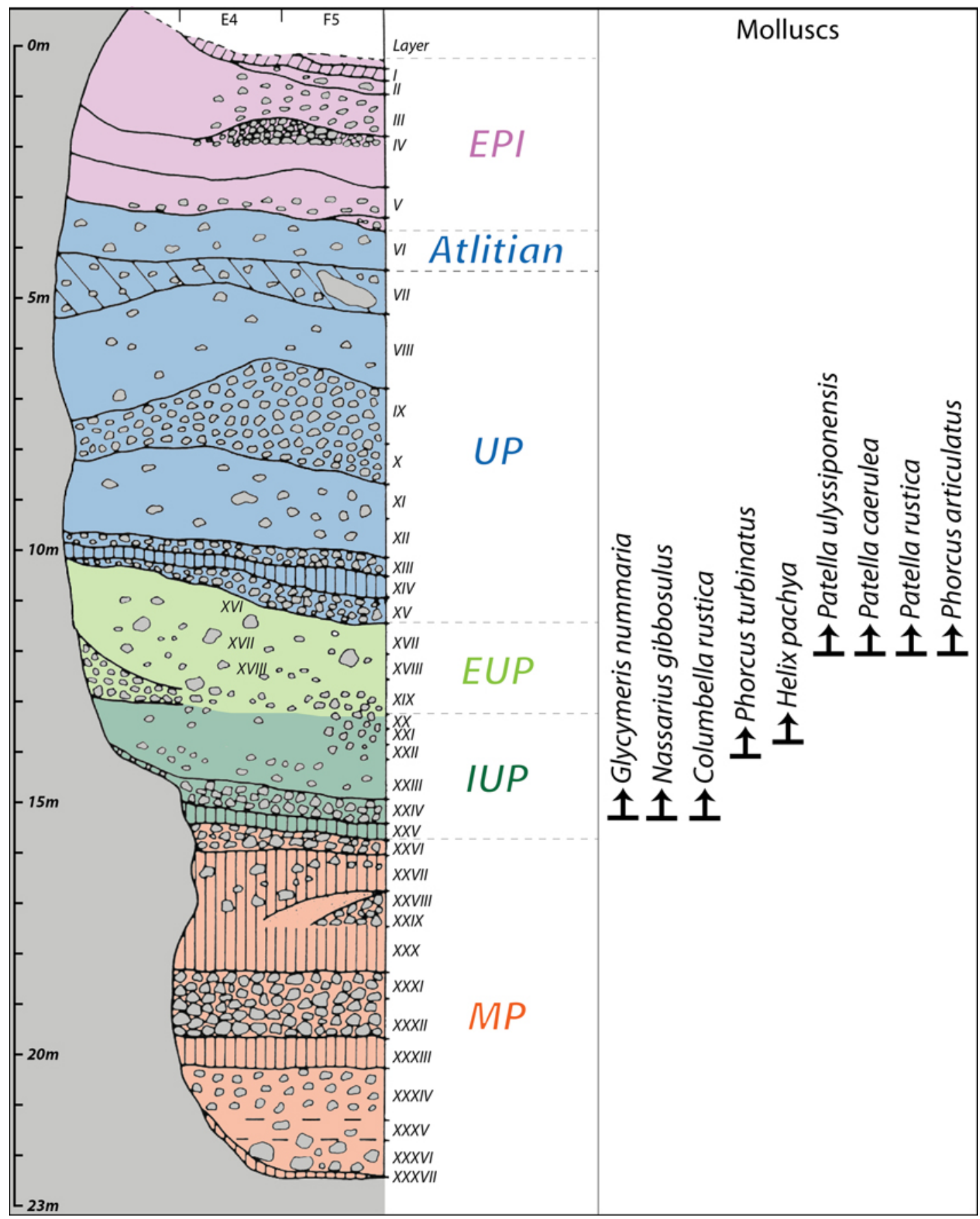



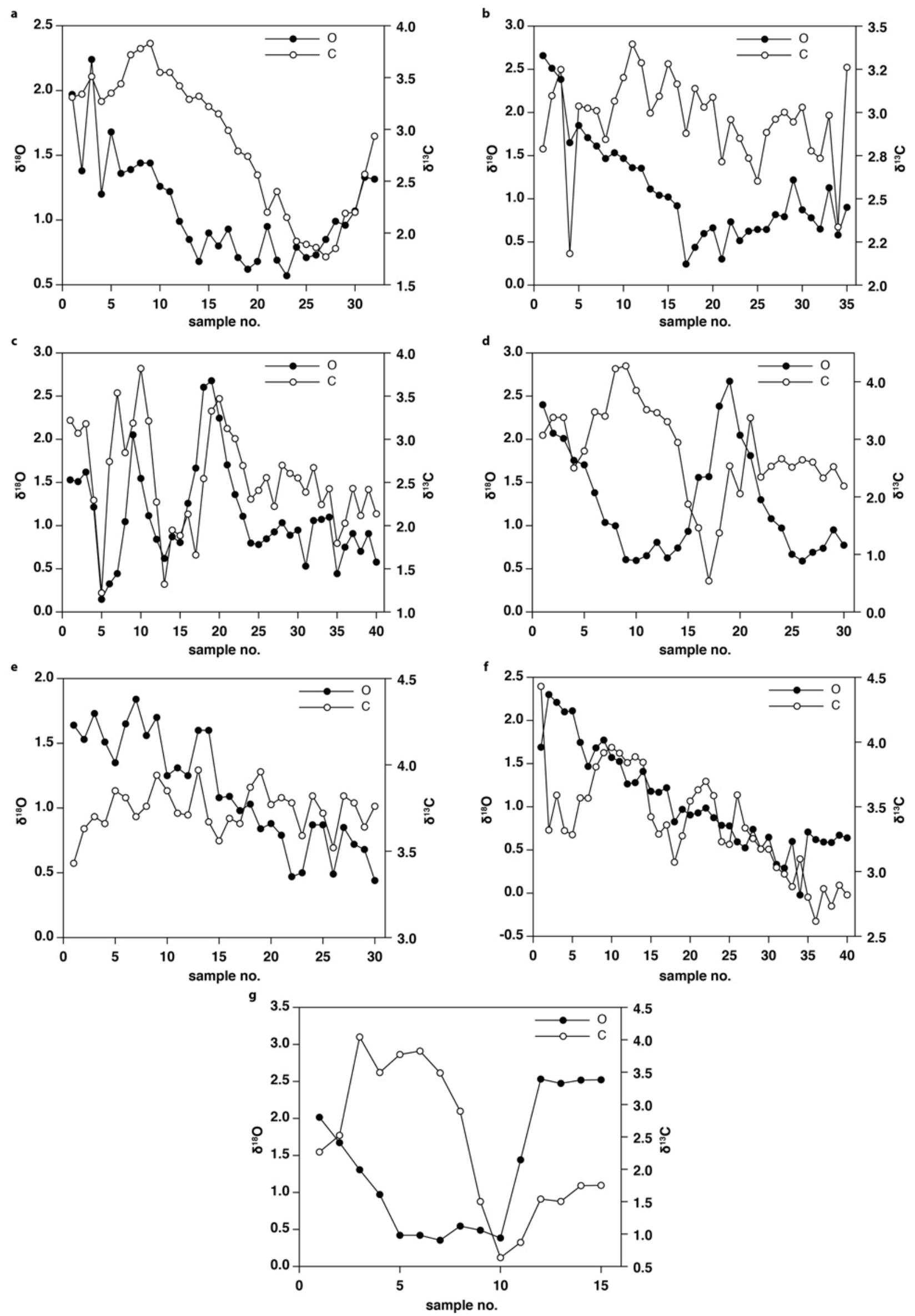

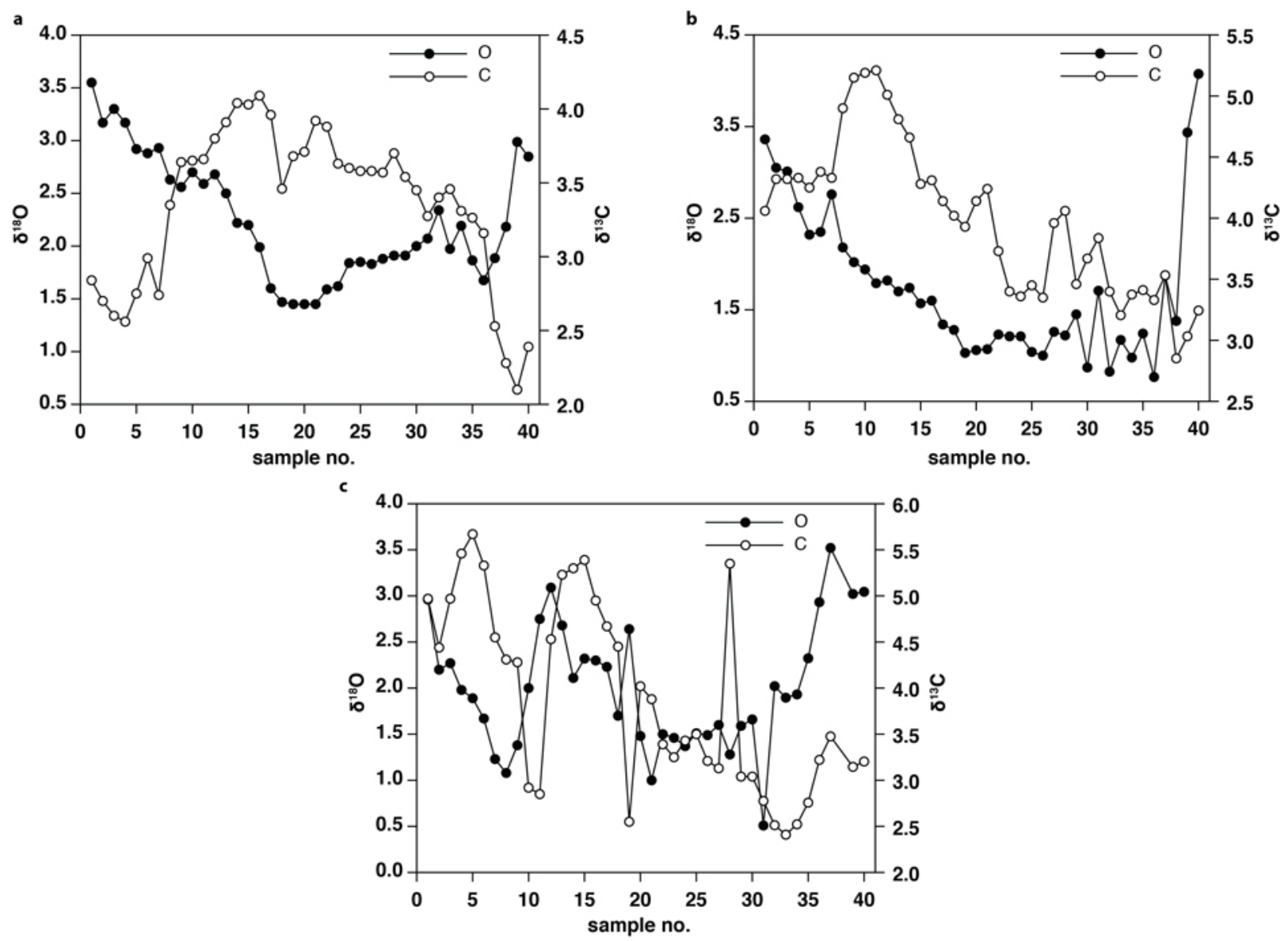

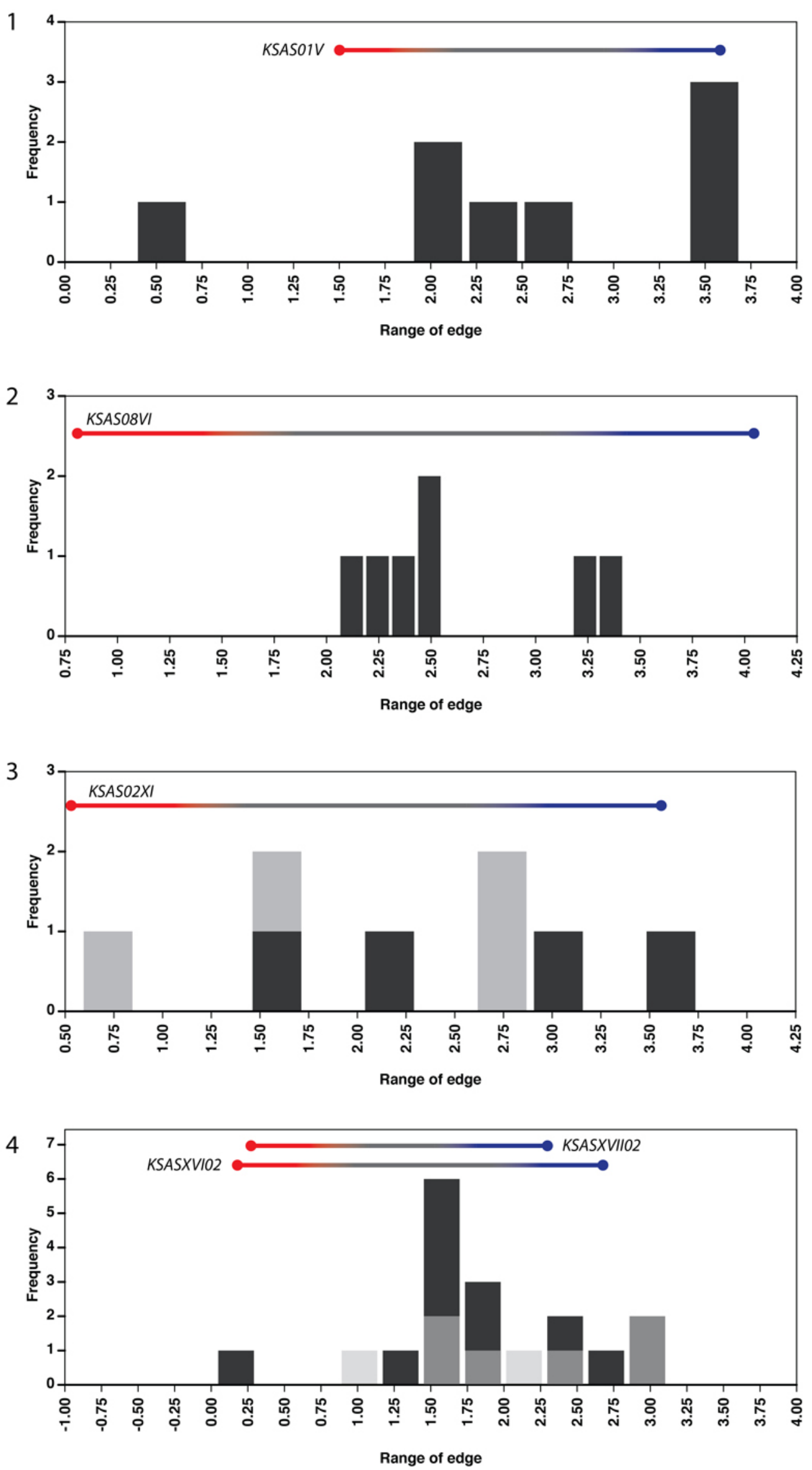

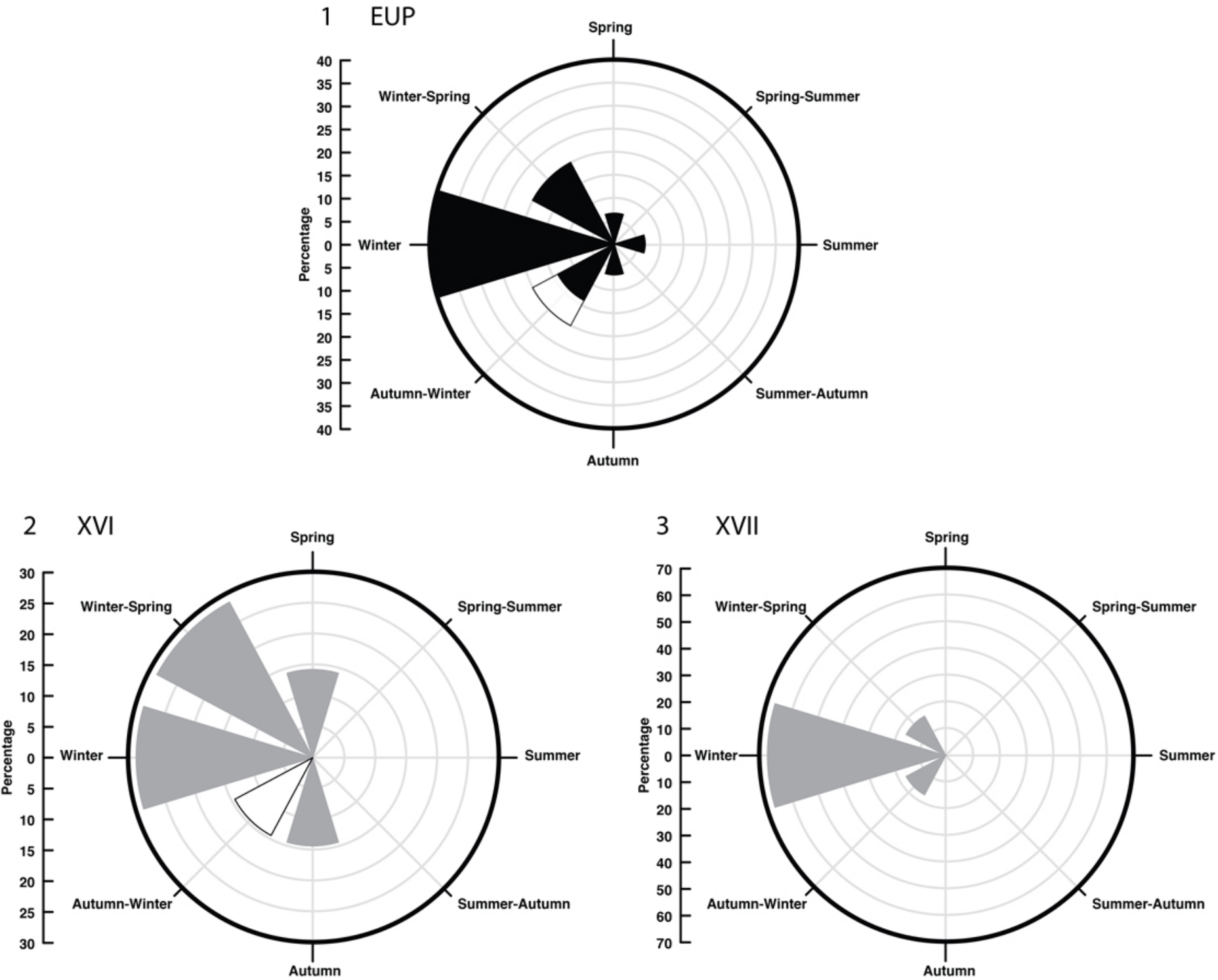

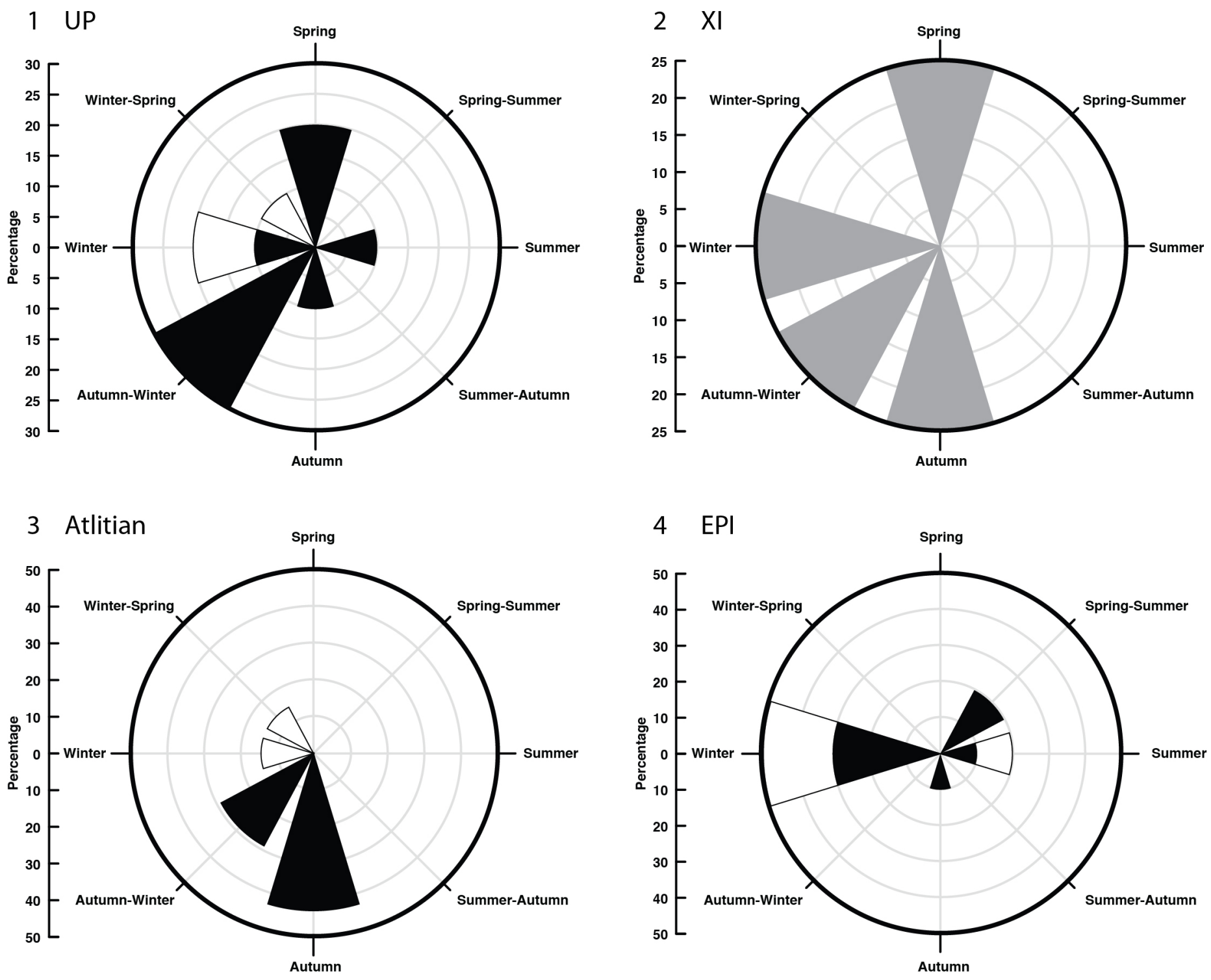